\title{
A regional ocean circulation model for the mid-Cretaceous North Atlantic Basin: implications for black shale formation
}

\author{
R. P. M. Topper ${ }^{1}$, J. Trabucho Alexandre ${ }^{1}$, E. Tuenter ${ }^{1,2}$, and P. Th. Meijer ${ }^{1}$ \\ ${ }^{1}$ Department of Earth Sciences, Faculty of Geosciences, Utrecht University, Utrecht, The Netherlands \\ ${ }^{2}$ Institute for Marine and Atmospheric Research Utrecht, Utrecht University, Utrecht, The Netherlands
}

Received: 12 October 2010 - Published in Clim. Past Discuss.: 29 October 2010

Revised: 14 February 2011 - Accepted: 15 February 2011 - Published: 21 March 2011

\begin{abstract}
High concentrations of organic matter accumulated in marine sediments during Oceanic Anoxic Events (OAEs) in the Cretaceous. Model studies examining these events invariably make use of global ocean circulation models. In this study, a regional model for the North Atlantic Basin during OAE2 at the Cenomanian-Turonian boundary has been developed. A first order check of the results has been performed by comparison with the results of a recent global Cenomanian CCSM3 run, from which boundary and initial conditions were obtained. The regional model is able to maintain tracer patterns and to produce velocity patterns similar to the global model. The sensitivity of the basin tracer and circulation patterns to changes in the geometry of the connections with the global ocean is examined with three experiments with different bathymetries near the sponges. Different geometries turn out to have little effect on tracer distribution, but do affect circulation and upwelling patterns. The regional model is also used to test the hypothesis that ocean circulation may have been behind the deposition of black shales during OAEs. Three scenarios are tested which are thought to represent pre-OAE, OAE and post-OAE situations. Model results confirm that Pacific intermediate inflow together with coastal upwelling could have enhanced primary production during OAE2. A low sea level in the pre-OAE scenario could have inhibited large scale black shale formation, as could have the opening of the Equatorial Atlantic Seaway in the post-OAE scenario.
\end{abstract}

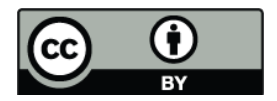

Correspondence to: R. P. M. Topper (topper@geo.uu.nl)

\section{Introduction}

In Mesozoic sequences all around the world, evidence of prolonged periods of enhanced organic carbon burial has been found related to so-called Oceanic Anoxic Events (OAEs). All previous modelling studies regarding the triggering mechanism for enhanced organic carbon burial and the associated ideas about (changes in) ocean circulation during Oceanic Anoxic Event 2 (OAE2), the subject of this study, have used global coupled ocean and atmosphere circulation models (e.g. Poulsen et al., 2001; Trabucho Alexandre et al., 2010). Horizontal resolution in these models is at best $2-$ $3^{\circ}$ in both latitudinal and longitudinal directions. Close to the equator, this results in grid cells of $\sim 200 \times 200 \mathrm{~km}$; for the North Atlantic Basin this comes down to a maximum of 400 grid cells in the horizontal plane. A more detailed approximation of palaeogeography can be made with a regional ocean-only model; the grid size can be reduced while at the same time the model runs much faster than the global equivalent because the total amount of grid points in the model has been reduced. The advantage of such a regional oceanonly model is that it allows for more sensitivity experiments and a higher resolution than a global ocean model, let alone a global climate model.

In order to benefit from these advantages, we have investigated the possibility of building a regional model dedicated to experiments on the circulation in the North Atlantic during the Cenomanian-Turonian boundary interval (CTBI). As a basis for this model, the MOMA (Modular Ocean Model Array, Haines and Wu, 1998) code for Mediterranean Sea models has been used (Webb et al., 1997). However, the regional ocean model does require specification of its interfaces with

Published by Copernicus Publications on behalf of the European Geosciences Union. 
those parts of the system left out: conditions at the open ends of the basin and at the water surface. In this study, these boundary conditions are derived from an existing Cenomanian CCSM3 run (Community Climate System Model version 3, Collins et al., 2006; Trabucho Alexandre et al., 2010; Sewall et al., 2007). Also initial fields for the regional model are derived from this CCSM3 run. The first question to be addressed is then whether the regional ocean model is able to maintain/reproduce the outcomes of the Cenomanian CCSM3 run. Although forced by global model results, regional model results can be different because of differences in resolution, palaeogeography and handling of boundary conditions..

If the regional model proves to be able to reproduce the main features of the CCSM3 results, the model can be used to examine some of the factors influencing circulation and upwelling patterns. Because upwelling zones are the zones where generally most organic matter is produced, the position of the modelled upwelling zones can be compared with the high organic matter contents found in southern North Atlantic sequences formed during the CTBI. Also, the cause of upwelling observed in the basin can be examined: is it wind driven or does it have another cause?

In reconstructions of the Cenomanian Atlantic bathymetry (e.g. Ross and Scotese, 1988; Sewall et al., 2007; Meschede and Frisch, 1998) there is some uncertainty about the presence and geometry of the connections between the global ocean and the Atlantic. We will perform sensitivity experiments to assess the effect of Pacific gateway geometry, the largest unknown factor in the bathymetry.

In addition, the model will be used subsequently to examine hypotheses about OAE2. In order to test the hypothesis that ocean circulation may be behind the initiation and wane of black shale deposition during OAE2 (Trabucho Alexandre et al., 2010), the regional model will be used to examine changes in the North Atlantic circulation for three different sets of boundary conditions, which are interpreted as representing scenarios for pre-OAE, OAE and post-OAE time envelopes. We will discuss (changes in) the circulation and upwelling patterns and the (anticipated) nutrient supply for all three scenarios to predict whether and where the conditions in the North Atlantic were favourable for black shale formation during each of these time envelopes.

\section{Oceanic Anoxic Events}

Oceanic Anoxic Events (Schlanger and Jenkyns, 1976) occurred at discrete intervals in the Mesozoic and have been extensively studied because of large scale source rock formation during these events. The best known of these events occurred in the mid-Cretaceous; OAE1a occurred in the early Aptian $(\sim 120 \mathrm{Ma})$ and, the focus of this research, OAE2 in the CTBI ( 93.6 Ma). During an OAE, unusually high amounts of organic matter accumulate in marine sediments (Jenkyns, 1980), generally called black shales because of their dark colour and thus regardless of lithology. OAE2 is defined by a global positive carbon isotope excursion, a $\delta^{13} \mathrm{C}$ increase of $>2 \%$, for which conservative and maximum estimates of the duration are 563-603 and 847-885 kyr respectively, as found at Pueblo, Colorado (Sageman et al., 2006).

The North Atlantic is the logical location in which to study OAE2 because the event was best developed in this basin. Around the CTBI the North Atlantic Basin was a land-locked basin with limited deep water connections to the global ocean (Fig. 1a). A deep water connection to the Pacific through the Central American Seaway (CAS) and shallow/intermediate water connections to the Tethys, through the Palaeo-Strait of Gibraltar (PSoG), and polar seas precluded complete isolation of the North Atlantic. This situation changed in the Late Cretaceous with the opening of the Equatorial Atlantic Seaway which forms the connection to the South Atlantic Ocean (Friedrich and Erbacher, 2006; Jones et al., 1995; Handoh et al., 1999; Pletsch et al., 2001; Poulsen et al., 2003).

The different driving mechanisms that have been proposed to account for the enhanced burial of high amounts of organic matter during an OAE, ultimately fall into two end-members: the mechanisms that lead to enhanced primary productivity and those that lead to anoxia. Enhanced primary productivity can be achieved by invigorated upwelling due to changes in wind patterns, increased river output or changes in shallow ocean circulation. Recycling of nutrients from already deposited organic matter has also been proposed as a mechanism to sustain high productivity during OAEs (Mort et al., 2007; Kuypers et al., 2004b). Strong anoxic conditions in the water column are most easily created when surface conditions inhibit deep water formation or all connections with the global ocean are closed which favours a sluggish water circulation. For the North Atlantic Basin, spillover of anoxic waters from the South Atlantic and anoxic water formation in restricted basins due to sea level fall have been proposed as causes of anoxia in the deep basin (Jeans et al., 1991). However, sea level during OAE2 was rising (Haq et al., 1987) which makes the latter mechanism less likely in a basin with connections to the open ocean. For this transgressive situation, Jenkyns (1980) proposed that in the expanding subtropical seas, primary productivity increased, using up all available oxygen in the surface waters. Due to enhanced evaporation, surface water became highly saline, causing these dense water masses to sink to the deep ocean (Barron and Peterson, 1991). This, in turn, would have allowed the mid-water oxygen minimum layer to expand throughout the water column.

All mentioned mechanisms for bottom water anoxia have been proposed without taking into account possible changes in redox conditions in the deep ocean before and during an OAE. Molecular fossils have been used to demonstrate that euxinic conditions, sometimes up to the photic zone, already existed before OAE2 in part of the North Atlantic (Kuypers et al., 2002; van Bentum et al., 2009; Kolonic et al., 2005). Therefore, changes in redox conditions at the seafloor cannot explain the sharp increase in the organic carbon burial 

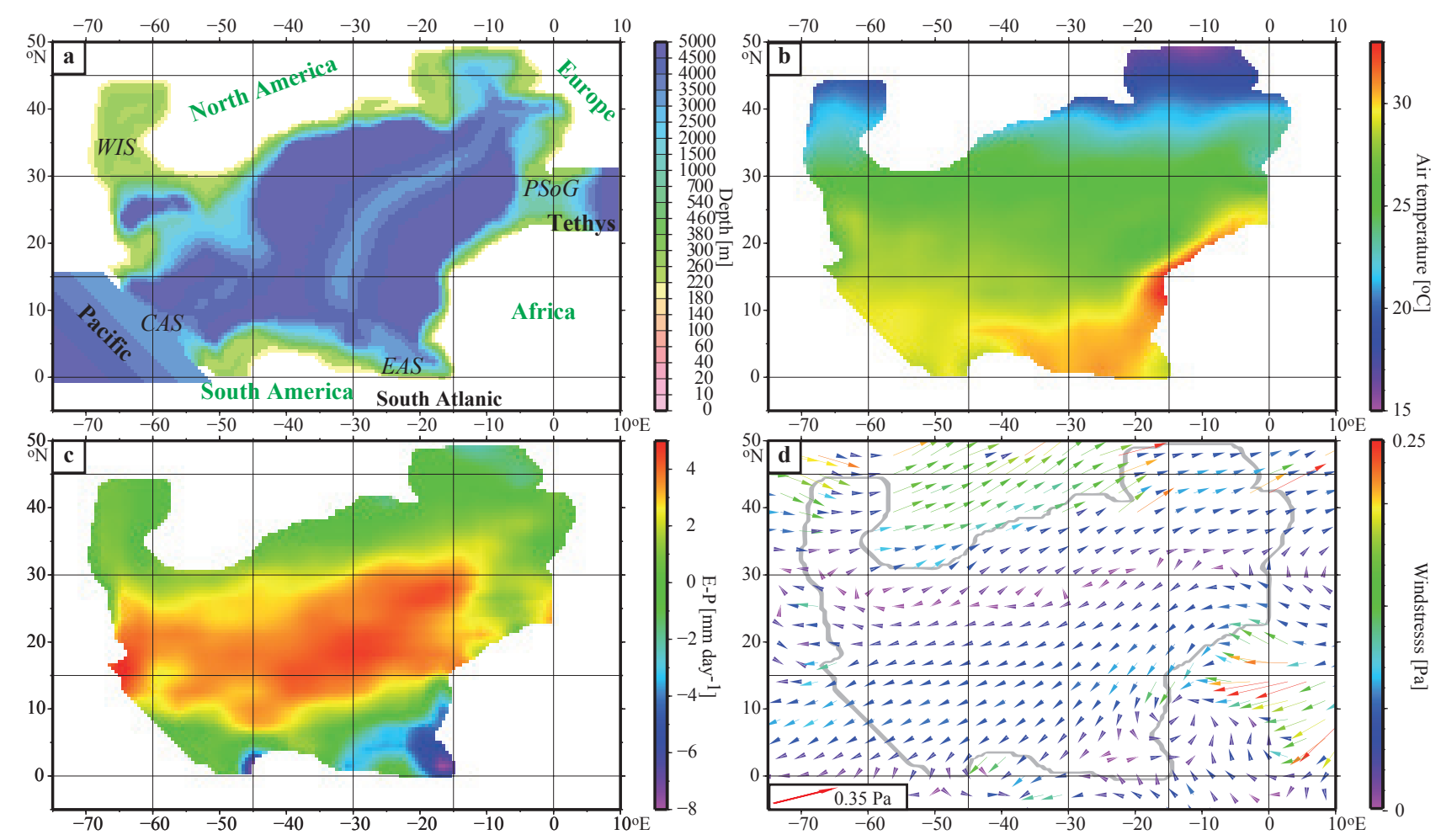

Fig. 1. Boundary conditions. (a) The bathymetry with 2 sponges attached; a Pacific sponge is connected at the Central American Seaway and a Tethys sponge at the Palaeo-Strait of Gibraltar. Not shown here is a third South Atlantic sponge which can be attached to the Equatorial Atlantic Seaway. (b) Air temperature at $2 \mathrm{~m}$ above the sea surface, (c) evaporation minus precipitation, and (d) windstress in the North Atlantic area are all 4-year averages from the atmospheric model of the Cenomanian CCSM3 run.

rate. Enhanced primary production up to three times the pre-OAE production was found in the southern part of the basin (Kuypers et al., 2002), which has been proposed to be caused by enhanced upwelling (Parrish and Curtis, 1982). A high organic matter flux to the sea floor, where it consumes the available oxygen for organic matter oxidation, is therefore proposed as the mechanism for the increased organic carbon burial rate (e.g. Kuypers et al., 2002, 2004a; Trabucho Alexandre et al., 2010; Barron and Washington, 1985; Piper and Calvert, 2009). Comparison of accumulation rates found at the north and south margins of the basin clearly indicates a higher primary production in the south (Sinninghe Damsté and Köster, 1998).

In any case, recent views on the black shale discussion are less polarised and it is now generally agreed upon that at least some primary productivity is needed to cause anoxia and that the latter enhances preservation of labile organic matter compounds.

\section{Model setup}

\subsection{Model description}

The Mediterranean version of MOMA (e.g. Webb et al., 1997), used as the basis for our model, is a geopotential height coordinate, primitive equation model adapted from the MOM from the Geophysical Fluid Dynamics Laboratory (Bryan, 1969; Pacanowski, 1995). The model parameters used in this study are summarized in Table 1.

The most important parameters for describing the dynamic state of the ocean are potential temperature, salinity, velocity and pressure. The evolution of these parameters in time at all points in the discretised ocean can be described by the ocean primitive equations. These consist of a three-dimensional momentum equation, an advection-diffusion equation for the tracers heat (temperature) and salt, a continuity equation and an equation of state (IES80, Fofonoff and Millard, 1983). In order to reduce the computational load of the model, the Boussinesq and hydrostatic approximations are made.

The horizontal resolution in all experiments presented in this study is $0.5^{\circ}$ in both latitudinal and longitudinal directions. The vertical resolution changes with depth: layers near the ocean surface have thicknesses of $10 \mathrm{~m}$ increasing to $500 \mathrm{~m}$ from $1000 \mathrm{~m}$ onwards. This depth-subdivision is 
Table 1. Model parameters.

\begin{tabular}{lll}
\hline Domain & Latitude & $-5-50^{\circ} \mathrm{N}$ \\
& Longitude & $-75-10^{\circ} \mathrm{E}$ \\
\hline Resolution & Horizontal & $0.5 \times 0.5^{\circ}$ \\
& Vertical & $10-500 \mathrm{~m}$ \\
\hline Timesteps & Baroclinic timestep & $4800 \mathrm{~s}$ \\
& Barotropic timestep & $80 \mathrm{~s}$ \\
\hline \multirow{2}{*}{ Horizontal mixing parameters } & Biharmonic eddy viscosity coefficient & $2 \times 10^{19} \mathrm{~cm}^{4} \mathrm{~s}^{-1}$ \\
& Biharmonic eddy diffusivity coefficient & $1 \times 10^{19} \mathrm{~cm}^{4} \mathrm{~s}^{-1}$ \\
\hline Vertical mixing parameters & Laplacian eddy viscosity coefficient & $1.5 \mathrm{~cm}^{2} \mathrm{~s}^{-1}$ \\
& Laplacian eddy diffusivity coefficient & $1 \mathrm{~cm}^{2} \mathrm{~s}^{-1}$ \\
\hline
\end{tabular}

adopted from the Mediterranean MOMA code (Haines and Wu, 1998) and extended to depths beyond $3000 \mathrm{~m}$ with 4 additional levels $500 \mathrm{~m}$ apart.

Following the constraints inherent to the numerical scheme (Pacanowski and Griffies, 1999), barotropic and baroclinic time steps of 80 and $4800 \mathrm{~s}$ ( $80 \mathrm{~min}$ ) have been chosen, respectively. Eddy viscosity and diffusivity coefficients values of $2 \times 10^{19}$ and $1 \times 10^{19} \mathrm{~cm}^{4} \mathrm{~s}^{-1}$ in the horizontal and 1.5 and $1.0 \mathrm{~cm}^{2} \mathrm{~s}^{-1}$ in the vertical are used (Table 1).

\subsection{Topography/bathymetry}

The model domain, the North Atlantic area at the CTBI $(\sim 93.6 \mathrm{Ma})$, is bounded by the latitudes $5^{\circ} \mathrm{S}$ and $50^{\circ} \mathrm{N}$ and the longitudes $75^{\circ} \mathrm{W}$ and $10^{\circ} \mathrm{E}$. In the horizontal, this gives $171 \times 111$ horizontal grid points. This area (Fig. 1a) includes, besides the North Atlantic Basin, gateways to the Arctic seas through the Western Interior Seaway (WIS) and the Norwegian Seaway, and gateways to the global ocean through the CAS (Pacific gateway), the EAS (South Atlantic gateway) and the PSoG (Western Tethys).

Müller et al. (2008) have recently created a database with continuously scaled, high resolution $\left(0.1^{\circ} \times 0.1^{\circ}\right)$ global bathymetry grid reconstructions considering only oceanic lithosphere, for the 140-0 Ma period with $1 \mathrm{Myr}$ intervals. The spatial resolution is high, but the data used for the reconstructions makes this possible; marine magnetic anomaly data, palaeomagnetic data and rotation poles together with information on mid-oceanic ridge subduction events and the rules of plate tectonics are either available at this resolution or known well enough to allow for this resolution. Detailed information about the reconstructions is beyond the scope of this paper, but can be found in the Supplement from Müller et al. (2008). We chose the bathymetry reconstruction at $90 \mathrm{Ma}$ as the basis for our bathymetry. It matches the CCSM landmass configuration better than the $93 \mathrm{Ma}$ reconstruction, which would have been preferable in view of the timing of OAE2.

The oceanic lithosphere reconstruction from Müller et al. (2008) has been discretised in depth to our 23 defined levels. The CCSM3 bathymetry, based on the reconstructions of C. R. Scotese, R. Blakey and published literature and constructed/adapted by Sewall et al. (2007), provides the information required to add a shelf to this oceanic lithosphere. After combining the two bathymetries, the resulting bathymetry is smoothed to avoid topographic instabilities at runtime and shelf depth is increased to $220-260 \mathrm{~m}$ to provide sufficient vertical grid cells to resolve shallow flow. The bathymetry is cropped to retain only the North Atlantic Basin and the gateways to the global ocean, hereby creating spaces in the grid to place 'sponges', in which temperature and salinity values are restored every time step to boundary conditions (Sect. 2.4).

Incorporation of features differing between the Müller et al. (2008) and CCSM bathymetries has been conducted with the intent to stay as close to the CCSM bathymetry as possible. The possible presence of the Great Caribbean Arc at the contact between the Farallon and Proto-Carribean plate (Pindell and Dewey, 1982) and the Caribbean Plateau basalts west of the CAS, as present in the bathymetry of Müller et al. (2008), have not been included in our bathymetry to avoid limitations to flow in the CAS (Sewall et al., 2007).

A connection to the South Atlantic Ocean by means of the EAS may have existed before the CTBI, but recent research shows no consensus on this subject (e.g. Moulin et al., 2009; Poulsen et al., 2003; Pletsch et al., 2001). We chose a palaeogeography with a closed EAS as our starting point. A South Atlantic sponge will be attached to the standard bathymetry to simulate a deep water connection to the South Atlantic Ocean only for the experiment in which the influence of a South Atlantic connection with the North Atlantic is examined.

The Palaeo-Strait of Gibraltar is present in all reconstructions with depths close to $700 \mathrm{~m}$ and is as such adopted from the CCSM model under the assumption that carbonate 
platforms in the Western Tethys do not inhibit intermediate water flow. The other global ocean connections are not put in the model palaeogeography because the CCSM3 results show that the inflow through these gateways is small.

Another important feature is the mid-oceanic ridge running from NE to SW in the main part of the North Atlantic (Müller et al., 2008). The CCSM3 bathymetry, on the other hand, contains no ridge; the main basin has a distorted bowl shape. Because a mid oceanic ridge is expected when active spreading takes place, it has been included in the bathymetry. Furthermore, it may pose a serious limitation to deep water flow in the basin.

\subsection{Surface boundary conditions}

The horizontal momentum equations and the tracer equations all contain a term describing the forcing of each parameter by processes at the surface. Surface processes influencing temperature and salinity are captured in a heat and water flux, respectively. For the horizontal velocities, wind stress is set at the surface boundary. All boundary conditions are extracted from the Cenomanian CCSM3 results and interpolated to our grid.

Validation of these boundary conditions is unfortunately very hard, if not impossible. The main reasons are the lack of other model simulations for a similar Cretaceous period and the lack of proxies for the required boundary conditions (e.g. Sewall et al., 2007). However, since our study focuses on sensitivity experiments, the boundary conditions are the same for all but one of the experiments and, consequently, will not influence the qualitative results from the regional model.

\subsubsection{Heat flux}

A simple standard restoring boundary condition is implemented in the model (Bryan and Cox, 1967; Cox, 1970). The air temperature is prescribed and the downward heat flux is calculated with

$Q=\rho C_{\mathrm{p}} \Gamma\left(T_{\text {air }}-T_{\text {surface }}\right)$

where $Q$ is the downward heat flux $\left[\mathrm{J} \mathrm{m}^{-2} \mathrm{~s}^{-1}\right], \rho$ is the density of seawater $\left[\mathrm{kg} \mathrm{m}^{-3}\right], C_{\mathrm{p}}$ is the specific heat of sea water, $\sim 3.9 \times 10^{3} \mathrm{~J} \mathrm{~kg}^{-1} \mathrm{~K}^{-1}, \Gamma$ is a relaxation coefficient which is dependent on the relaxation time scale and the upper ocean layer thickness, $\Gamma=\Delta z / \Delta t_{\text {relax }}$. With a relaxation time of 10 days, similar to the relaxation time scales used by Rahmstorf (1995) and Rahmstorf and Willebrand (1995), $\rho C_{\mathrm{p}} \Gamma$ becomes $42 \mathrm{~kJ} \mathrm{~m}^{-2} \mathrm{~s}^{-1} \mathrm{~K}^{-1}$.

The heat flux is calculated every time step with an updated upper ocean layer temperature and an invariable surface air temperature throughout the year, obtained from the $2 \mathrm{~m}$ air temperature of the CCSM3 results (Fig. 1b). Air temperatures decrease, as expected, when moving to higher latitudes. Deviations from this trend can be found near the continental landmasses of Africa and South America where the air temperature is a few degrees higher. Part of this is related to the warm surface waters coming from the South Atlantic in the CCSM3 results (Sect. 2.5), while a predominantly westward wind over the African continent may account for the rest.

\subsubsection{Water flux}

The easiest way of including the surface water flux is introducing a virtual salt flux (VSF) calculated from the average evaporation minus precipitation data from the CCSM3 run (Fig. 1c). Differences between models with a boundarymodel freshwater flux and VSF have proved to be generally small or statistically insignificant (Yin et al., 2010).

Because the volume of water in a grid cell is not changed, there is one disadvantage to using a VSF: when a water flux is included in the model by means of a VSF, the amount of water entering a grid cell through the surface must be small compared to the grid cell volume. Large volumes of water therefore cannot be added to a single grid cell with the VSF without inducing a significant error in the salinity.

Evaporation is in most of the Cretaceous North Atlantic (Fig. 1c) dominant over precipitation, with large parts showing net evaporation of $2-5 \mathrm{~mm}$ day $^{-1}$. The only exceptions to this are areas along the North American coast where precipitation locally exceeds evaporation on a yearly basis by $2 \mathrm{~mm} \mathrm{day}^{-1}$, and along the South American and African coasts where precipitation is significantly higher and reaches values up to $9 \mathrm{~mm} \mathrm{day}^{-1}$.

\subsubsection{Windstress}

In the horizontal momentum equations, the momentum flux through the sea surface comes from wind stress (Fig. 1d) and momentum transfer in connection with a fresh water flux. The latter is disregarded as its size is small compared to the wind stress. 4 year averaged zonal and meridional wind stress components are taken from the CCSM3 run results.

\subsection{Sponges}

The Mediterranean version of MOMA has the possibility of attaching sponges to deal with the "open" boundaries of a regional model. Strictly speaking these are not boundary conditions since they are positioned within the main computational domain. The sponges are areas in the model where temperature and salinity values at all depth levels are restored every time step to the salinity and temperature fields of the CCSM3 run. These CCSM3 fields are also used as initial conditions for the North Atlantic Basin in all of the experiments (Sect. 2.5). The restoration timescale, implemented by means of a Newtonian damping term in the tracer equations, is 1 day in those parts of the sponges more than 5 grid cells away from the gateway and decreases linearly to zero towards the gateways. For example, salinity and temperature of water flowing from the North Atlantic into the Pacific 
sponge are (partly) restored to the salinity and temperature of the Pacific, as found in the CCSM3 run, before the water flows back into the North Atlantic Basin with these "Pacific" characteristics. The decreasing restoration timescale towards the gateways gradually reduces the density contrast between sponge and basin which otherwise could have limited exchange and induced non-physical flow at the gateways.

The first use of this type of sponge with the MOMA is from Roussenov et al. (1995), who justified it as a way "[...] to control areas of the model which are not well resolved.". It had been used before in other regional ocean models (e.g. Philander et al., 1987) and has since been widely used for Mediterranean ocean circulation research (e.g. Haines and Wu, 1998; Meijer et al., 2004).

Our regional model used in this study can be equipped with 3 sponges (Fig. 1a) to simulate water exchange with the global ocean. Depending on the configuration needed for each of the experiments, one or more of these sponges can be attached to the model through a gateway with a changeable geometry (depth, width, full bathymetry).

Constant-depth sponges would introduce unrealistic bathymetric gradients, enhance undesirable upwelling and decrease water exchange with the North Atlantic Basin. Therefore smooth bathymetric profiles have been constructed for the sponges. With these, the vertical transport of water in the sponges from depths below gateway depth proceeds with more gradual upward water transport and higher horizontal velocities in the gateway.

\subsection{Initial conditions}

The initial conditions for all experiments consist of prescribed tracer fields of temperature and salinity (Fig. 2) with which the density structure of the ocean is defined directly. These fields are interpolated from the 4-year average salinity and temperature data of the CCSM3 run. All experiments start with zero velocity fields.

In the first $100 \mathrm{~m}$ of the CCSM3 results, the majority of the basin is affected by inflow from the Tethys which flows diagonally through the basin to the Pacific and westwards from the gateway and back east in a western boundary current along the North American coast. At slightly greater depths, between 100 and $700 \mathrm{~m}$, relatively cold water flows in from the Pacific and Tethys. In the upper part of this depth interval, this cold water follows the coasts of Africa and South America. At a greater depth, the cold water spreads out over the whole southern half of the North Atlantic Basin. The current from the Tethys to the Pacific marks the separation between cold southern water and warm northern water. The latter flows in a clockwise gyre between 25 and $40^{\circ} \mathrm{N}$. High temperature gradients form above $700 \mathrm{~m}$ between the northern and southern part of the basin. At a depth of $700 \mathrm{~m}$ the PSoG sill is reached and inflow from the Tethys ceases. This causes disintegration of the Tethys-Pacific current, as well as of the high temperature gradient, until both are completely gone at $1000 \mathrm{~m}$. Below $1000 \mathrm{~m}$ depth the temperature is almost uniform and equals that of the Pacific. Not present in our reference experiment is an inflow of warm surface water from the South Atlantic, which dominates the temperature distribution in the southern North Atlantic down to $100 \mathrm{~m}$.

The salinities in the North Atlantic show a pattern similar to that of temperature. Surface salinities are dominated by the net evaporation over most of the basin, a South Atlantic and Tethys inflow, and extremely low salinities $\left(20 \mathrm{gl}^{-1}\right)$ in the continental seaways. At depth, the southern half of the basin is less saline than the northern half, again separated by the current between the Tethys and Pacific. At depths below $1000 \mathrm{~m}$, salinities are approximately uniform at $35.5 \mathrm{~g} \mathrm{l}^{-1}$.

\section{Analysis and results}

\subsection{Reference experiment}

The first model configuration tested (REF, Table 2) features the simplest geometry and boundary conditions. Attached to the North Atlantic Basin are two sponges with gateway depths of 3000 and $700 \mathrm{~m}$, similar to depths in the CCSM3 bathymetry, simulating respectively the Pacific and Tethys oceans. This experiment will be used to gain insight into ocean circulation and tracer (temperature and salinity) distribution in a regional model for the case that the North Atlantic was connected only to the Pacific and Tethys (i.e. no connection with the South Atlantic ocean or with the Arctic region). Results will be compared with the CCSM3 results to assess to what extent this regional model is able to reproduce the main features of the global model results. Because each experiment starts with the initial (CCSM3) salinity and temperature field, the spin up of the model is short ( $<200$ years). Figures and values presented for the regional model are averages of the last 50 years of a 500 year run when basin-averaged as well as layer-averaged tracer values are constant and confirm that the model has reached an equilibrium state.

The salinity in the North Atlantic is characterized by a strong meridional gradient across the basin between 15 and $25^{\circ} \mathrm{N}$ at depths down to $1000 \mathrm{~m}$ (Fig. 3). The low salinities in the southern part of the basin are similar to the deep water salinity in the Pacific sponge. At depths between 700 and $3000 \mathrm{~m}$ there is a net inflow from the Pacific supplying the southern part of the North Atlantic Basin with relatively low salinity water. In the upper $50 \mathrm{~m}$ of the ocean, low salinity Tethyan water enters the North Atlantic. Most of this Tethyan water flows in a band westwards to the Pacific (Fig. 3). The largest salinity gradients in this experiment are associated with this geostrophic flow across the basin; the largest salinity gradient is encountered north of South America at $15^{\circ} \mathrm{N}$ where within $\sim 250 \mathrm{~km}$, a salinity difference of $2.5 \mathrm{~g} \mathrm{l}^{-1}$ (from 36-38.5 g l${ }^{-1}$ ) can be observed. Another part of the Tethyan surface inflow is transported to the northeastern part of the basin (Iberian coast), where it is taken up in 


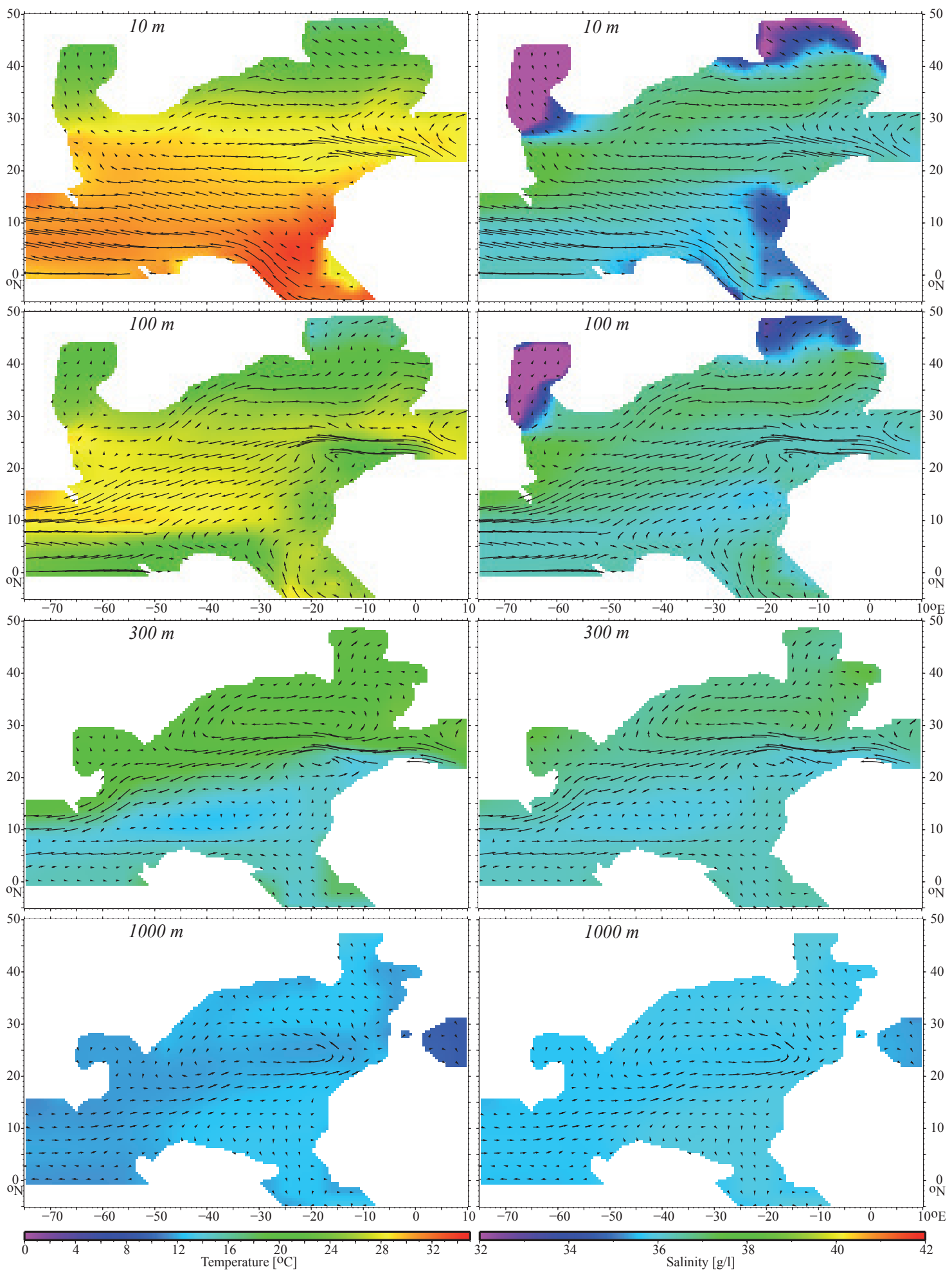

Fig. 2. Initial conditions. The temperature (left column) and salinity (right column) from the CCSM 3 results at the surface and depths of 100,300 and $1000 \mathrm{~m}$ going from top to bottom. Lines show the paths water particles would travel in 30, 54, 84 and 114 days (particle trace time increasing with depth) keeping the average mean velocity field from the same CCSM3 results constant. For clarity, only every fifth grid point is followed. The temperature and salinity shown here are used to set the initial density field in the model, and the value to which relaxation takes places in the sponges, and are used for comparison with regional model results. 
Table 2. Experiments. All experiments in this study and the CCSM3 run, and corresponding figures are listed here. Abbreviations for: IC, initial conditions; BC, boundary conditions; Pac/Tet/SAtl, Pacific/Tethys/South Atlantic gateway depths; SL, sea level.

\begin{tabular}{llllllll}
\hline & IC & BC & Pac & Tet & SAtl & SL & Fig(s). \\
\hline CCSM & - & - & $3000 \mathrm{~m}$ & $1000 \mathrm{~m}$ & $1000 \mathrm{~m}$ & High & $2,5 \mathrm{~b}$ \\
REF & CCSM & CCSM & $3000 \mathrm{~m}$ & $700 \mathrm{~m}$ & Closed & High & $3-6$ \\
ISOIC & $15^{\circ} \mathrm{C} / 35 \mathrm{~g} \mathrm{l}^{-1}$ & CCSM & $3000 \mathrm{~m}$ & $700 \mathrm{~m}$ & Closed & High & - \\
NOWIND & CCSM & No winds & $3000 \mathrm{~m}$ & $700 \mathrm{~m}$ & Closed & High & 7 \\
SILLED & CCSM & CCSM & $1000 \mathrm{~m}$ & $700 \mathrm{~m}$ & Closed & High & S1 \\
PACN & CCSM & CCSM & Open N & $700 \mathrm{~m}$ & Closed & High & - \\
PACS & CCSM & CCSM & Open S & $700 \mathrm{~m}$ & Closed & High & - \\
SATL & CCSM & CCSM & $3000 \mathrm{~m}$ & $700 \mathrm{~m}$ & $3000 \mathrm{~m}$ & High & $8,9 a, 10 a$, S2 \\
LOWSL & CCSM & CCSM & $3000 \mathrm{~m}$ & $500 \mathrm{~m}$ & Closed & Low & - \\
LOWSL-TET & CCSM & CCSM & $3000 \mathrm{~m}$ & $200 \mathrm{~m}$ & Closed & Low & $9 \mathrm{~b}, 10 \mathrm{~b}, 11$ \\
\hline
\end{tabular}

a large gyre in the northern part of the basin reducing the salinity of its waters.

Another source of low salinity water is the net precipitation along the coasts of South America and Africa (Fig. 1c) where it contributes to the formation of relatively low salinity surface waters. The total precipitation in the coastal areas is $0.8 \mathrm{~Sv}$ (Sverdrup $=10^{6} \mathrm{~m}^{3} \mathrm{~s}^{-1}$ ), significantly less than the Pacific and Tethyan inflow. Only the surface layer is affected by precipitation, at $40 \mathrm{~m}$ depth all precipitation effects are indistinguishable in the "background" salinity.

In the northern part of the basin, the surface water flux is also the main reason for the high salinities. The total evaporation flux from the North Atlantic has a magnitude of $1.3 \mathrm{~Sv}$. Evaporation minus precipitation has the largest values in the center of the North Atlantic where it reaches net evaporation rates of $6 \mathrm{~mm} \mathrm{day}^{-1}$. The highly saline surface waters have a density larger than the layers below and mix or sink causing the salinity in the lower layers to increase as well until density differences are too small to continue vertical movements.

The boundary between the warm saline northern $\left(>15^{\circ} \mathrm{N}\right)$ and colder, less saline southern part is marked by the presence of a geostrophic Tethys-Pacific-directed current between 12 and $17^{\circ} \mathrm{N}$ and depths down to $700 \mathrm{~m}$ (Fig. 3). This current is part of a large scale clockwise flow in the northern part of the basin and, next to the Tethys-Pacific current, consists of a western boundary current along the North American shelf. The eastern part of this gyre is less clear, the western boundary current splits up in a broad zone with predominantly southward flow, in which horizontal velocities decrease and vertical velocities increase. Along all American, African and, to a lesser extent, European coasts the opposite can be observed: shallow water velocities increase where deep water comes to the surface in coastal upwelling zones (Fig. 5a).

At deeper levels, the southern boundary of the northern gyre is positioned further north(-west) with respect to the surface layer (Fig. 4). While the gyre becomes smaller with depth, the Tethys-Pacific flow band becomes smaller and retains its velocity, leading to high velocities in the whole northern gyre. At a depth of $500 \mathrm{~m}$, velocities and elevated salinities decrease rapidly towards basin average values at $1500 \mathrm{~m}$ where the Tethys-Pacific flow band has completely disintegrated and salinities in the whole basin are homogeneous at $\sim 35.6 \mathrm{~g}^{-1}$.

At depths greater than $300 \mathrm{~m}$, a temperature front exists with a maximum temperature difference of $5{ }^{\circ} \mathrm{C}$ between a warm northern and cold southern part of the basin, which fades out at depth as cold water enters the central part of the basin from the Pacific. In the top $140 \mathrm{~m}$ there is no steep temperature gradient between the northern and southern parts of the basin. This surface layer temperature is strongly connected to the surface air temperature.

While surface salinity of the Tethys is similar to the salinity along the African coast, its temperature is very different. The warm surface water from the Tethys can be traced straight to the west, but horizontal and vertical velocities (Fig. 5a) also indicate strong downwelling and upwelling near the PSoG. Cold, low-salinity intermediate water is upwelled in the coastal zone where it replaces the warm water from the Tethys, and flows southwestwards along the African coast. In the salinity figures (Fig. 3), this process is harder to recognize because Tethyan and deep water have similar salinities. In general, upwelling in the African coastal zone is widespread and effectively reduces salinities and temperature in the upper $500 \mathrm{~m}$.

At depths as shallow as $40 \mathrm{~m}$ a pronounced low temperature area $\left(20^{\circ} \mathrm{C}\right.$ at this depth) is present between the African and South American continents. Between 40 and $300 \mathrm{~m}$ this area expands gradually towards the Pacific gateway while it forms the large temperature gradient at $\sim 15^{\circ} \mathrm{N}$. This temperature anomaly can be explained by upwelling of cold Pacific deep water replacing the warmer shallow water. In Fig. 4, the effect of this process is visible in shoaling of the isotherms towards the east (EW-sections) and south (NS-sections). Another feature of the circulation and upwelling along the South 

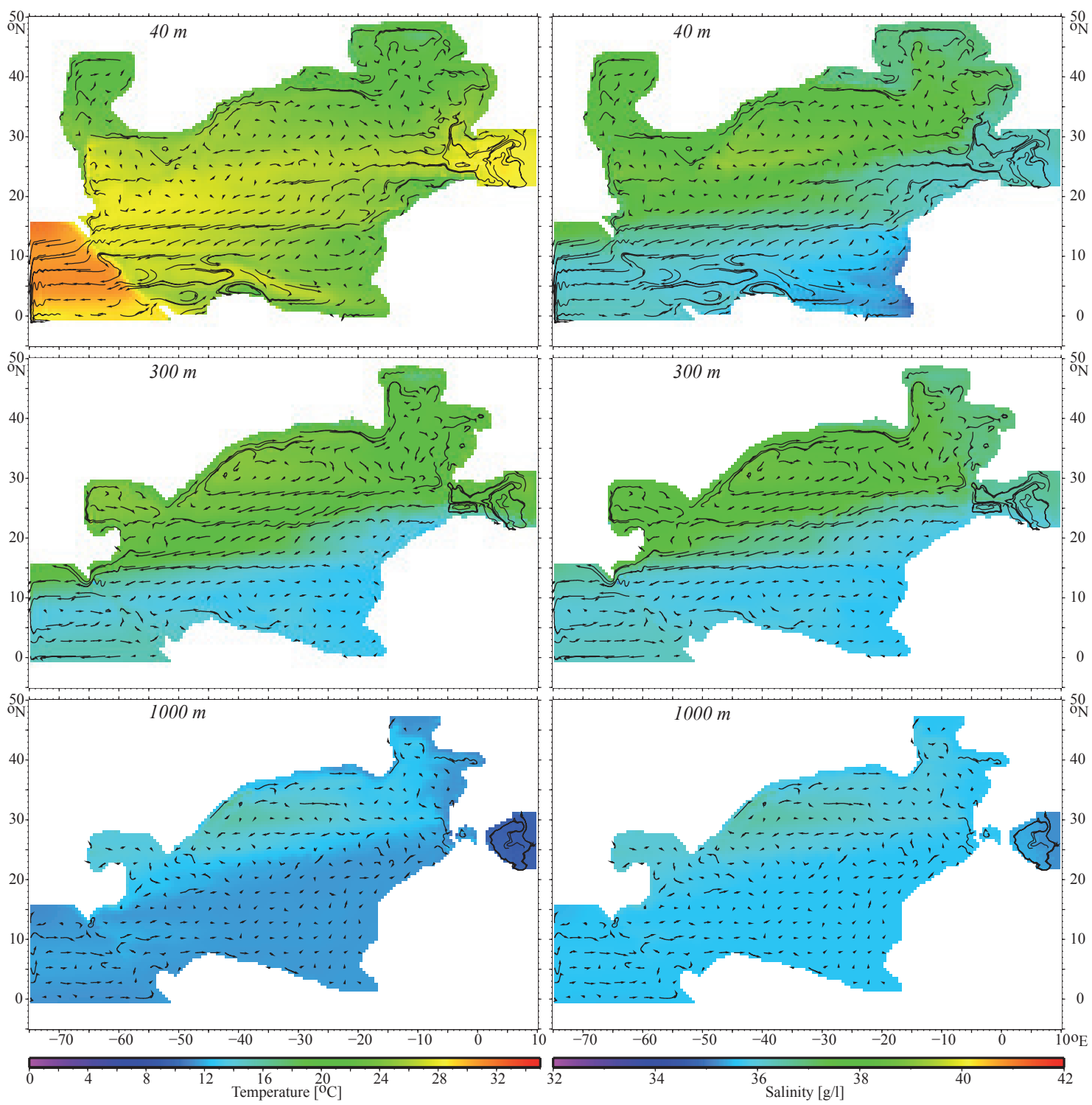

Fig. 3. REF tracer patterns. Temperature (left) and salinity (right) slices taken at depths of 40, 300 and $1000 \mathrm{~m}$. The paths of water particles of every fifth grid point followed for 42,84 and 114 days are overprinted on the tracer colours. In order to visualize low velocity currents at deeper levels, the time during which water particles are followed increases with depth.

American coast is the presence of mesoscale eddies extending to depths of $300 \mathrm{~m}$; cyclonic eddies are associated with upwelling, anticyclonic eddies with downwelling.

Total inflow from the Pacific is $48 \mathrm{~Sv}$ with the main inflow concentrated at depths between 1000 and $2500 \mathrm{~m}$ and outflow spread over shallower depths. The Tethyan inflow is smaller at $32 \mathrm{~Sv}$. In the PSoG, the westward volume flux peaks in the upper $300 \mathrm{~m}$, the eastward flux in the deeper layers. The circulation with respect to the Pacific is estuarine (i.e. shallow out, deep in), with respect to the Tethys it is antiestuarine (i.e. shallow in, deep out). In order to visualize the overall basin circulation, we computed the zonal overturning streamfunction (Fig. 6). The zonal overturning rate is
$21 \mathrm{~Sv}$, and is concentrated in a single cell with counterclockwise flow in a west-to-east section (Fig. 6). The maximum depth of significant overturning decreases from the Pacific to the Tethys in correspondance to their respective gateway depths of 3000 and $700 \mathrm{~m}$. Zonal transport into and out of the sponges as it follows from the streamfunction in Fig. 6 is less than the inflow values quoted just now. The reason for this is that the streamfunction sums up, for a given depth, flow from all latitudes with the effect that adjacent inflow and outflow will partly cancel each other out. 

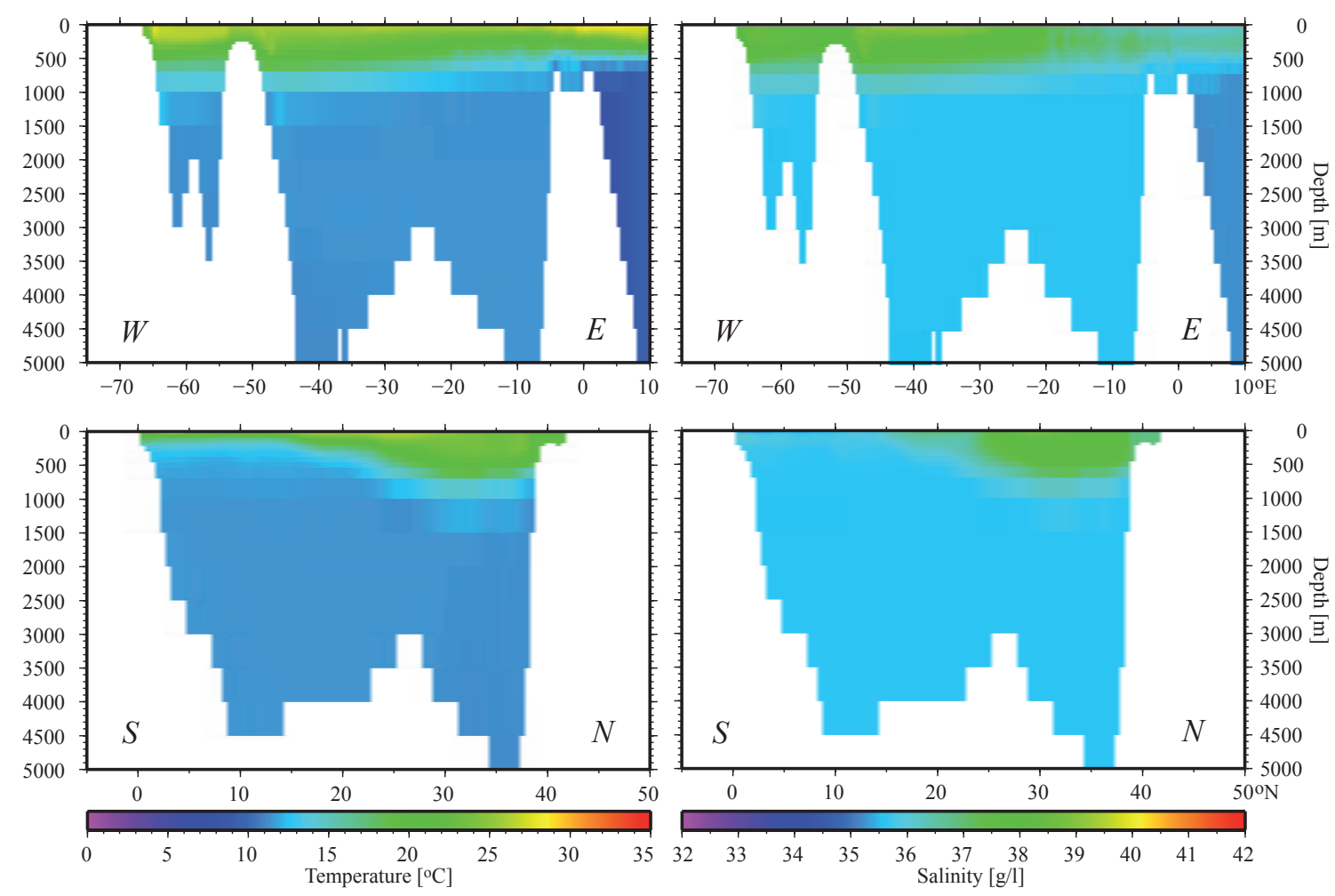

Fig. 4. REF cross sections. Two sets of cross sections of temperature (left) and salinity (right) give an overview of the tracer distribution in the vertical direction. The west-east sections are taken at $27.5^{\circ} \mathrm{N}$ and the south-north sections at $25^{\circ} \mathrm{W}$.
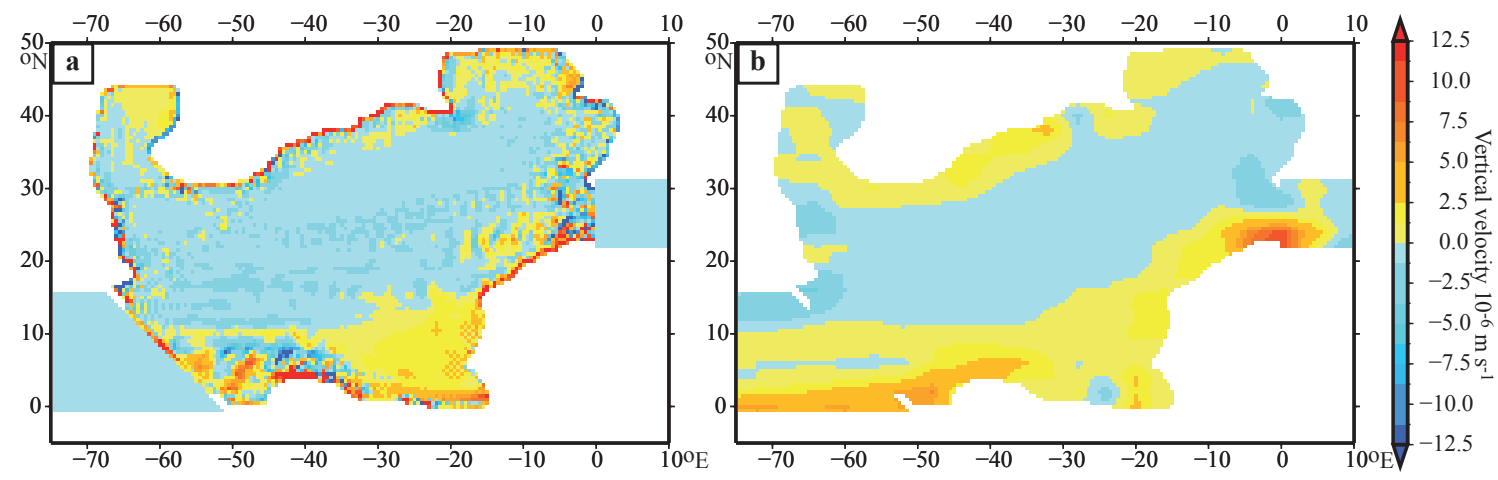

Fig. 5. Upwelling. Mean vertical velocity at $40 \mathrm{~m}$ from (a) REF and (b) the Cenomanian CCSM3 run. Upward velocities are positive and downward negative. $10 \times 10^{-6} \mathrm{~m} \mathrm{~s}^{-1}$ corresponds to $\sim 0.86 \mathrm{~m} \mathrm{day}^{-1}$.

In summary, the main features of the REF experiment are: a front in temperature and salinity between the northern and southern North Atlantic emphasized by an east-west directed current between the Tethys and Pacific, a large clockwise gyre in the northern half of the basin and a large coastal upwelling zone in the south, and zonal overturning consisting of one large counterclockwise cell. A summary of the quantifiable results of all experiments is given in Table 3.

A new experiment (ISOIC) with isothermal $\left(15^{\circ} \mathrm{C}\right)$ and isohaline $\left(35 \mathrm{~g}^{-1}\right)$ initial values in the whole basin and the standard boundary conditions was run to verify or refute the idea that the initial temperature and salinity in the model affect the circulation pattern produced eventually. The results from this experiment prove nearly identical to the results of REF and are not shown. It follows that the initial temperature and salinity distributions have no influence on the final results. However, the use of the CCSM3 results for the initial values halves the time needed for an experiment to get to an equilibrium situation in the basin, and at start-up a larger timestep can be used because tracer gradients at the sponge boundaries are small. 
Table 3. Results. Summary of results.

\begin{tabular}{lccccccc}
\hline & \multicolumn{2}{c}{ Basin average } & \multicolumn{3}{c}{ Inflows [Sv] } & \multicolumn{2}{c}{ Overturning [Sv] } \\
\hline & $S[\mathrm{~g} / \mathrm{l}]$ & $T\left[{ }^{\circ} \mathrm{C}\right]$ & Pacific & Tethys & S-Atl. & Zonal & Meridional \\
\hline REF & 35.793 & 12.855 & 47.8 & 32.4 & - & 21 & 15 \\
NOWIND & 35.832 & 12.908 & 35.5 & 24.8 & - & 18 & 12 \\
SILLED & 35.888 & 13.381 & 30.1 & 50.4 & - & 20 & 15 \\
PACN & 35.804 & 12.884 & 32.3 & 29.0 & - & 18 & 18 \\
PACS & 35.774 & 12.830 & 42.0 & 29.7 & - & 18 & 25 \\
SATL & 35.837 & 13.060 & 61.0 & 27.1 & 32.1 & 27 & 15 \\
LOWSL & 35.747 & 12.706 & 38.7 & 25.4 & - & 18 & 15 \\
LOWSL-TET & 35.792 & 12.776 & 40.0 & 5.4 & - & 12 & 6 \\
\hline
\end{tabular}

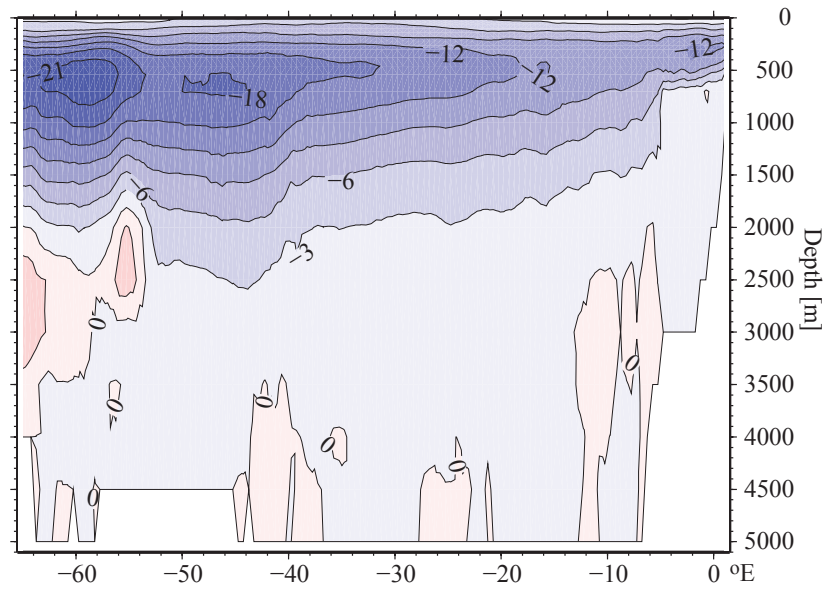

Fig. 6. REF zonal overturning. Zonal overturning in the North Atlantic Basin. Contour lines are drawn every $3 \mathrm{~Sv}$, blue colours indicate negative (counterclockwise in this view) overturning and red colours positive (clockwise). In the East, this graph stops at the Tethys sponge while the boundary with the Pacific sponge does not run $\mathrm{N}-\mathrm{S}$. Consequently, west of $52^{\circ} \mathrm{W}$ the overturning streamfunction shown is affected by overturning in the sponge. The positive cells between 2000 and $4000 \mathrm{~m}$ are an artifact hereof.

Besides a slightly larger northern gyre, both horizontal velocities and patterns of upwelling are largely similar in the CCSM3 and REF. The Tethys-Pacific flow band and the diminishing size of the northern gyre with depth are found in both models, as well as upwelling in all coastal areas and extensive upwelling in the southern part of the basin and along the African coast. Small differences between the experiments can be found in the surface circulation pattern where, as mentioned before, the CCSM3 includes an inflow of South Atlantic water to a depth of $100 \mathrm{~m}$ which we choose not to implement in the reference experiment.

When looking into the differences in more detail, the volume averaged temperature difference between CCSM3 and our reference experiment is less than $0.01^{\circ} \mathrm{C}$. Larger differences occur in the upper $100 \mathrm{~m}$ (the upper 5 layers of the model) where the average difference is $2{ }^{\circ} \mathrm{C}$. A main contributor to this difference is the upwelling zone between the African and American continents (Fig. 5); this is warmer in the CCSM3 because the South Atlantic inflow counteracts the cold upwelling. However, an almost uniform difference of $1.4{ }^{\circ} \mathrm{C}$ can be attributed to a weaker surface heat flux in our model caused by a different parametrization of the surface heat flux and a less vigorous vertical mixing in the top layers. At intermediate depth, local differences up to $5^{\circ} \mathrm{C}$ occur in the northwestern part of the North Atlantic and the proto-Gulf of Mexico south of the WIS. The northern gyre in REF extends to these areas enclosing warm saline water, while it is limited to more eastern longitudes in the CCSM3 run.

Salinity differences are larger than temperature differences with an average of about $0.04 \mathrm{~g} \mathrm{l}^{-1}$. Salinity is consistently higher with $1.0 \mathrm{~g}^{-1}$ in the upper $100 \mathrm{~m}$ with respect to the CCSM3 due to the fact that we do not include a small coastal runoff (fresh water) flux in the surface forcing and, again, to more vigorous vertical mixing in the top layers. Areas with anomalously large differences are the WIS and the area between North America and the European shelf where the North Atlantic is connected to the polar seas in the CCSM3. Inflow from these areas, however, is very small $(0.6 \mathrm{~Sv})$ and does not create differences outside the surface layers. The extended gyre in the northern North Atlantic also has its effect on the salinities which can be up to $2 \mathrm{~g} \mathrm{l}^{-1}$ higher.

Because of the similarity in the results from our regional model and the CCSM3 model, this experiment will be used as the reference experiment when, in the next sections, sensitivity tests are presented. This experiment has been chosen instead of an experiment with a connection to the South Atlantic because the influence of the small surface inflow is local and such small exchange flows are hard to reproduce with a sponge. The focus will be on the effects of wind forcing, the presence of open-ocean connections and the associated geometry of the gateways and their connection to the North Atlantic. 


\subsection{Wind forcing and upwelling}

Understanding the cause of the modelled upwelling is important to deduce what ultimately drives the system towards higher productivity and associated black shale formation, especially during OAEs. Upwelling is generally associated with winds acting on the sea surface inducing transport in the Ekman layer. To assess the importance of wind on upwelling, a model has been run (NOWIND) which is a restart of REF without surface wind forcing.

Without winds, mixing between surface and deeper water layers decreases significantly. This results in temperatures in the upper $20 \mathrm{~m}$ of the basin being similar to the air temperature, due to the imposed relaxation, and salinities are strongly influenced by the fresh water flux. The average temperature difference with respect to the CCSM3 in the upper $100 \mathrm{~m}$ has decreased in this experiment, while the salinity difference increased. Reduced shallow-water mixing enhances the amount of heat and salt stored in the surface layers. At $200 \mathrm{~m}$ depth, a division between a warm, saline northern and cold, less saline southern part of the basin forms which exists down to $1500 \mathrm{~m}$. The division is formed in a similar way as in REF. Although similar in formation, the northern gyre is much smaller without wind as the Tethyan inflow goes straight to the west instead of diagonally through the basin. In the southern part of the basin, flow directions vary strongly, but the general transport direction is to the southwest. Changes with respect to REF include also a decreased inflow from the Pacific, $36 \mathrm{~Sv}$, and Tethys, $25 \mathrm{~Sv}$. Although the circulation has changed and gateway transport has decreased, zonal overturning is little affected by the lack of wind forcing; it is still dominated by one negative cell, i.e. anti-clockwise flow in a WE-section, with a strength of $18 \mathrm{~Sv}$.

The main difference with respect to REF concerns the upwelling pattern which has changed dramatically in the upper $300 \mathrm{~m}$. With wind stresses, upwelling was concentrated in the coastal areas. Now it is virtually homogeneous throughout the whole basin without clear upwelling zones near the coasts (Fig. 7). Also, the warm and cold cored mesoscale eddies along the South American coast have completely disappeared. Flow along the South American coast is now concentrated in a small east-west directed current parallel to the coast. The only persistent upwelling zone that influences tracer distribution is the area between 0 and $5^{\circ} \mathrm{N}$ in between Africa and South America, where the deep water inflow from the Pacific is still upwelled to the surface (Fig. 7).

From the results of NOWIND it can be deduced that the concentrated upwelling zones as well as the mesoscale eddies are driven by wind. In REF, upwelling in the southern part of the basin is stronger, with respect to the north, because all wind stresses are approximately WSW directed over large areas of sea surface. Ekman transport in the upper part of the ocean is directed NW up to latitudes of $20^{\circ} \mathrm{N}$ where the average wind stress changes direction to NE. The area where both surface currents meet is positioned exactly above the

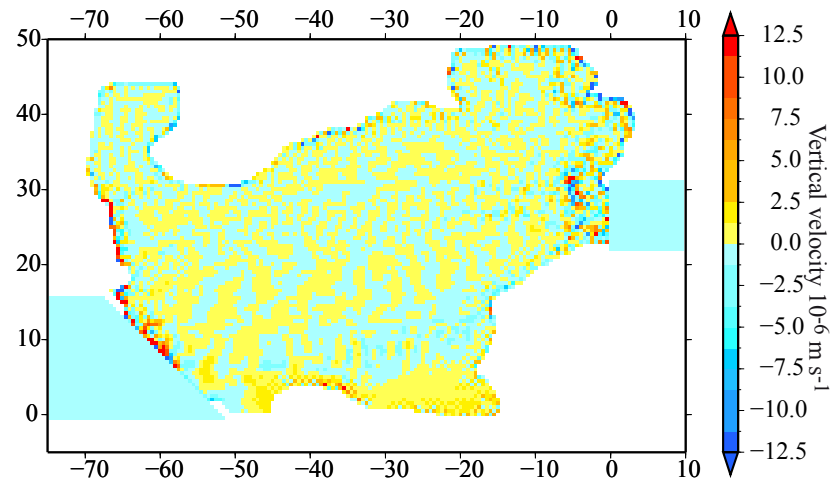

Fig. 7. Upwelling without wind. Vertical velocity at $40 \mathrm{~m}$ depth for the NOWIND experiment.

warm-cold boundary at deeper levels (Fig. 3). Warm saline surface waters in the Ekman layer in the northern part of the basin sink on the northern side, cold less saline waters on the southern side. Without this supply of surface waters to the deeper levels in NOWIND, the deep part of the northern gyre is not supplied with warm saline water any more.

The mesoscale eddies observed in REF can be compared with the cold- and warm-cored rings that form on both sides of the present-day Gulf Stream. Wind stresses on the surface cause baroclinic instabilities by upwelling and downwelling water, which trigger the formation of these eddies on both sides of the west-directed current; warm-cored eddies form on the north side of the current, cold-cored eddies on the south side. If instead of a time-averaged, a set of consecutive time slices were taken from the circulation pattern, it could be seen that the eddies move along the coast and disintegrate when they lose strength and reform around $45^{\circ} \mathrm{W}$.

\subsection{Gateway geometry effects}

\subsubsection{Sill depth of the gateways}

As mentioned before, the depth of the gateways, especially the depth of the CAS, is a point of discussion in reconstructions of the CTBI palaeogeography. In the bathymetry of previous experiments, the maximum depth at which exchange with the Pacific was possible through the CAS was $3000 \mathrm{~m}$. In principle it is expected that a shallower connection with the Pacific would inhibit deep water exchange and hence influence conditions in the North Atlantic. This has been tested by placing a sill with a depth of $1000 \mathrm{~m}$ in the CAS (SILLED experiment) leaving the PSoG at its original $700 \mathrm{~m}$ depth.

Pacific inflow is similar to REF with $48 \mathrm{~Sv}$ with half the total inflow below $700 \mathrm{~m}$. Also, Tethyan inflow decreases slightly to $30 \mathrm{~Sv}$ due to a weaker zonal overturning circulation. Although volumes of inflow have changed, the changes in the circulation pattern are relatively small in the upper $1000 \mathrm{~m}$. The southern boundary of the northern gyre shifts a few degrees to the north as the balance between cold, less 
saline water in the basin is skewed with respect to REF in favour of the cold, less saline water. Also, the Tethys-Pacific flow band contains more variation in flow directions and delivers more cold, less saline water to the northern gyre. At all depths, the influence of the additional intermediate Pacific inflow is noticeable (Fig. S1, Supplement). From 1000 to $3000 \mathrm{~m}$ a downward current is active just east of the sill, transporting slightly warmer and more saline water, with respect to deep Pacific water, to these depths. This warm saline water is transported through the whole basin by two main currents along the northern and southern coasts where they feed the upwelling zones. As a result, the temperature and salinity in the north decrease slightly while they increase in the south, reducing the differences in the basin. Deep water $(>1000 \mathrm{~m})$ in the North Atlantic reaches average temperatures $0.5^{\circ} \mathrm{C}$ and salinities $0.1 \mathrm{~g} \mathrm{l}^{-1}$ higher than in REF. At gateway depths the increased average temperature in the North Atlantic increases the density contrast with the Pacific, driving a stronger exchange flow which is not evident from the weaker overturning of $20 \mathrm{~Sv}$ because of meridional averaging. The depth of significant overturning also increases to $2500 \mathrm{~m}$ in relation to lower density differences in the water column.

\subsubsection{Width of the Atlantic-Pacific gateway}

The second sensitivity test with respect to the Pacific gateway geometry relates to the effects of a reduced CAS width. The bathymetry in the sponge and basin are close to the standard bathymetry. The only difference is the width of the CAS; in the experiment PACN the southern $6^{\circ}$ of the CAS have been turned to land to leave an open connection in the North, in PACS the width has been reduced from the north with the same amount.

Reducing the cross sectional area of the gateway results in a lower total Pacific inflow, $32 \mathrm{~Sv}$ for PACN (42 for PACS) versus $48 \mathrm{~Sv}$ in REF. The flow pattern through the gateway has changed more dramatically than in the SILLED experiment. Inflow in the upper $300 \mathrm{~m}$ has become negligible and decreases further in the 1000 to $3000 \mathrm{~m}$ depth range. Inflow from the Tethys is also slightly lower in both experiments (29 Sv).

The changes in tracer distribution in the basin are mainly the result of a shift in the position of Pacific inflow. The Tethys-Pacific flow band still dominates the flow between the surface and $1000 \mathrm{~m}$ in both PACN and PACS, but there are small shifts in its position. The reduced surface inflow in PACN has been forced to the north which causes $0.5-1.5^{\circ} \mathrm{C}$ cooling with respect to REF in the upper $200 \mathrm{~m}$ along the whole South American coast. At intermediate depth, relatively warm Pacific waters flow along the coast and feed the upwelling zones, while simultaneously the northern gyre stays warmer $\left(\sim 1^{\circ} \mathrm{C}\right)$ because of this shifted current. In PACS, the whole Tethys-Pacific flow is shifted to the south causing a small expansion of the northern gyre and a colder southern basin due to the increased upwelling of Pacific water as expressed also by the increased meridional overturning $(25 \mathrm{~Sv})$. Overall, the tracer and large scale circulation patterns are little affected by changes in the gateway width.

\subsection{An open Equatorial Atlantic Seaway}

This and the next section present the results of two experiments examining pre-OAE and post-OAE scenarios. The post-OAE contains a deep water connection with the South Atlantic through the EAS (SATL experiment). This has been shown to refresh the basin (Poulsen et al., 2003) and is expected to change the large scale circulation pattern and associated upwelling.

The open two-way connection between the North Atlantic Basin and the South Atlantic Ocean is implemented by means of a South Atlantic sponge. The gateway has a width of $10^{\circ}(\sim 1000 \mathrm{~km})$ and depths of 300 to $3500 \mathrm{~m}$, with the greatest depths close to the African continent, similar to the CCSM3 bathymetry.

The net inflow of warm surface water from the South Atlantic as found in this experiment $(1.7 \mathrm{~Sv})$ is very close to the $1.8 \mathrm{~Sv}$ observed in the CCSM3 results. In the CCSM3, the whole western North Atlantic is affected, while here the warm saline water in the surface layer is trapped near the gateway where it flows along both continents to downwelling zones (Fig. 8; Jones et al., 1995). At depths up to $2500 \mathrm{~m}$, the South Atlantic temperatures and salinities are higher than those in the North Atlantic and both the inflow and the downwelling of saline water are clearly visible in the cross-sections (Fig. S2, Supplement). The upwelling zone of the deep Pacific water situated between Africa and America is suppressed by the inflow and is cut by a large coast parallel downwelling zone of warm saline South Atlantic and surface water (Fig. 9a). In all previous experiments, an east- flowing deep current supplied water to the upwelling zones along the South American coast; here it has been replaced with a westflowing current of warmer, more saline South Atlantic water (Fig. 8).

The northern gyre and the warm saline water it traps are affected by the South Atlantic inflow ( $32 \mathrm{~Sv}$ ). The deep water inflow of Pacific cold, low salinity water is strongly reduced and forced to the north by the South Atlantic warm, saline water which occupies the whole southern and eastern North Atlantic at depth. Simultaneously, a deep current (>1500 m) transports a small part of the Pacific inflow along the North American coast to the north where it is caught in the coastal upwelling zone. The upwelling water in the North and the north-westward driven southern boundary result in a weakening and narrowing of the gyre which extends to only $750 \mathrm{~m}$ depth in this experiment.

The zonal overturning circulation is stronger $(27 \mathrm{~Sv})$ and extends to depths of $4000 \mathrm{~m}$. The layers below $2500 \mathrm{~m}$, which were hardly moving in the reference experiment, are 

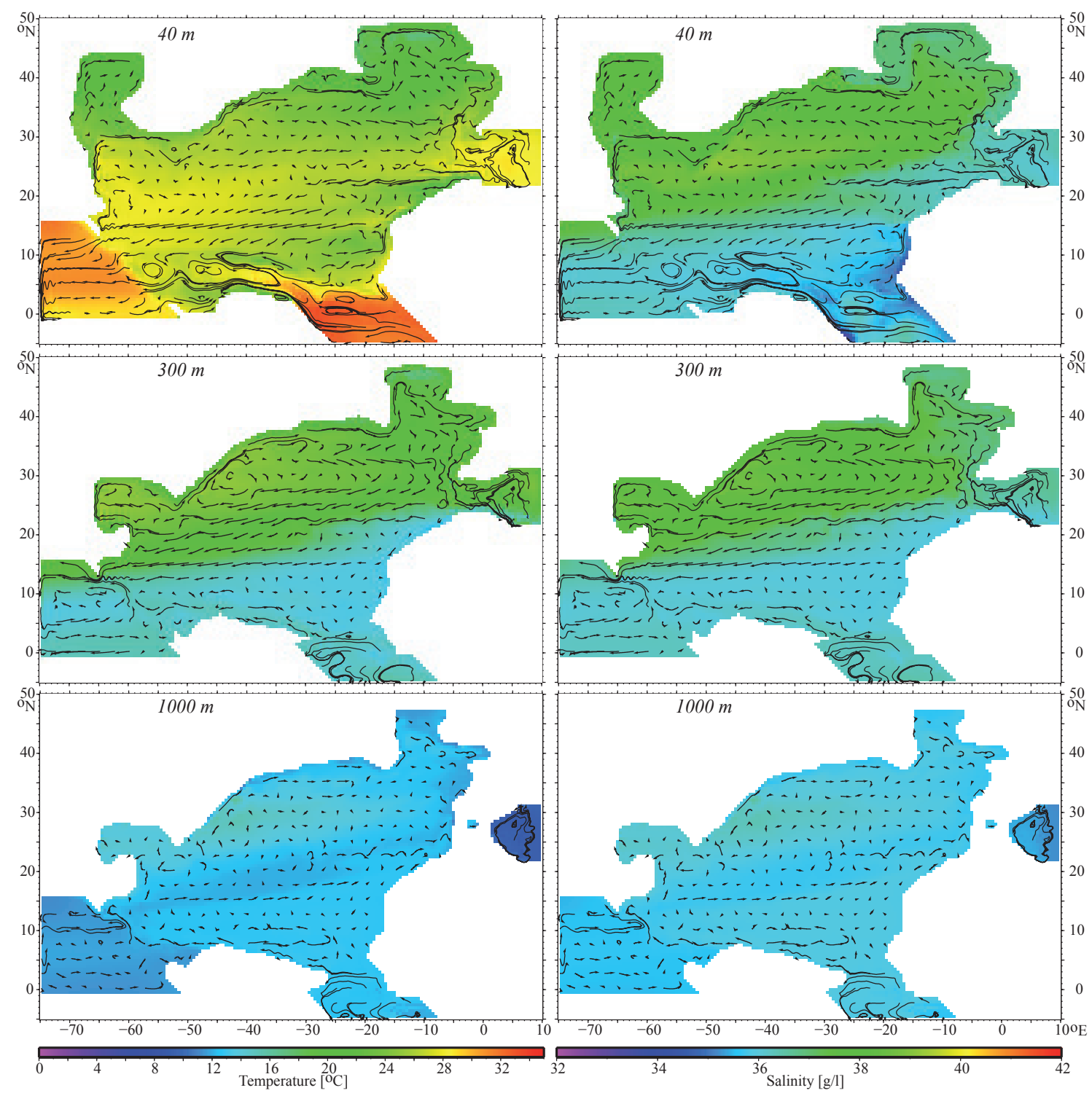

Fig. 8. SATL tracer patterns. Temperature (left) and salinity (right) slices taken at depths of 40, 300 and $1000 \mathrm{~m}$ from the SATL experiment. Overprinted on the tracer colours are the paths of waterparticles of every fifth grid point followed for 42, 84 and 114 days.

now brought into motion by the density contrast between Pacific and South Atlantic water.

\subsection{Lowered sea level}

All productivity related OAEs in the Mesozoic coincide with a marine transgression. For a pre-OAE scenario, we therefore lowered the sea level with $150 \mathrm{~m}$ with respect to REF, resulting in the exposure of large areas of the epicontinental shelf area and a shallowing of the gateways (LOWSL experiment). For the PSoG, sea level change results in a maximum gateway depth of $550 \mathrm{~m}$, the CAS depth does not change because such a small change is below the resolution of the model in deep water.
The shallowing of the PSoG is reflected in the gateway exchange. Flow from the Tethys lowers to $25 \mathrm{~Sv}$ ( $32 \mathrm{~Sv}$ in $\mathrm{REF}$ ) while CAS exchange is also lower at $39 \mathrm{~Sv}$ ( $48 \mathrm{~Sv}$ in REF). Relatively to North Atlantic averages, the Tethys inflow is colder and less saline. Reduced inflow therefore results in higher Atlantic salinities and temperatures, on average $0.1 \mathrm{~g} \mathrm{l}^{-1}$ and $0.15^{\circ} \mathrm{C}$ in the upper $1000 \mathrm{~m}$, respectively. These values would have been higher if the Pacific-derived water at depths below the Tethys gateway had not intruded the northeastern part of the basin and fed the upwelling along the European coasts. Zonal overturning is shallower and drops to $19 \mathrm{~Sv}$ due to the decreased Tethyan exchange.

The reduced shelf area causes a basinward shift in the upwelling zones and consequently to deeper water. In general 

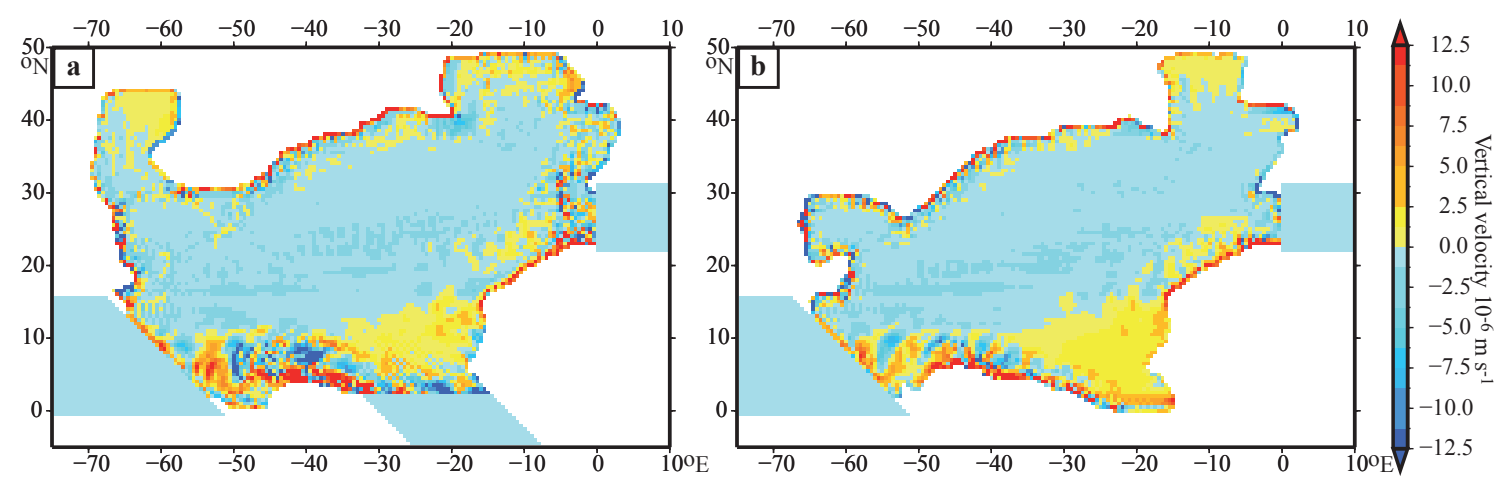

Fig. 9. Upwelling. Modelled vertical velocity at $40 \mathrm{~m}$ depth for an experiment with (a) an open connection with the South Atlantic through the EAS (SATL), and (b) a reduced shelf area due to low sea level (LOWSL-TET).
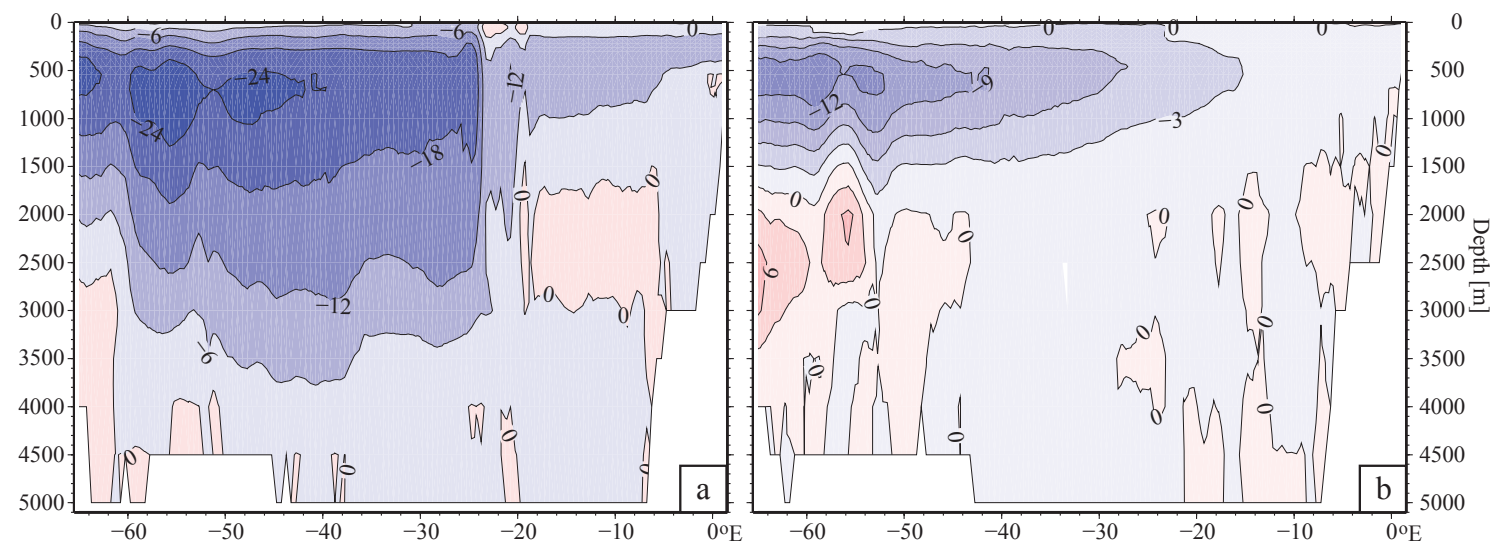

Fig. 10. Overturning. Zonal overturning in the North Atlantic Basin for the SATL experiment (left) and the LOWSL-TET experiment (right). Contour lines are drawn every $3 \mathrm{~Sv}$, blue colours indicate negative (counterclockwise) overturning and red colours positive (clockwise).

the density contrast along the coasts is low and eddies are weaker. The areal extent of the upwelling zone between South America and Africa is reduced by at least one third and instead of upwelling along the southern coasts, deep water is transported north-eastwards to the European coasts.

If we assume that carbonate platforms in the western Tethys inhibited intermediate water exchange between the North Atlantic and Tethys before the latest Cenomanian transgression, a model with a shallower Tethys sponge may be more appropriate. Results of two more experiments with a $200 \mathrm{~m}$ deep PSoG (LOWSL-TET experiment) and a closed PSoG are very similar because the exchange with the Tethys is only $5 \mathrm{~Sv}$ in the former. The small Tethyan inflow flows along the African coast down to $15^{\circ} \mathrm{N}$ and shifts the entire Tethys-Pacific flow to this latitude (Fig. 11). This results in higher salinities (with respect to REF) at shallow to intermediate depth due to a southwards extended northern gyre. The trend to higher temperatures, however, does not continue; upwelling of deep water from the Pacific has further increased along the European coasts (Fig. 9b).
The largest change with respect to the experiments with a deeper Tethys gateway is, however, not in the tracer patterns but in the overturning. Although inflow from the Pacific is still $40 \mathrm{~Sv}$, the zonal overturning in the North Atlantic has decreased in strength to only $12 \mathrm{~Sv}$ (Fig. 10b). Furthermore, the overturning cell extends to only $1500 \mathrm{~m}$ and is largely absent east of $15^{\circ} \mathrm{W}$ due to the missing Tethyan inflow.

\section{Discussion}

\subsection{MOMA}

Our regional model has proven to be a good complement to a global model for (sensitivity) experiments in a dedicated region. However, some limitations and boundary conditions which should be mentioned are inherent to this regional model.

The constructed bathymetry for the North Atlantic Basin approximates the bathymetry of the CTBI as closely as possible on the basis of the various reconstructions of that time, and it is certainly an improvement with respect to global 

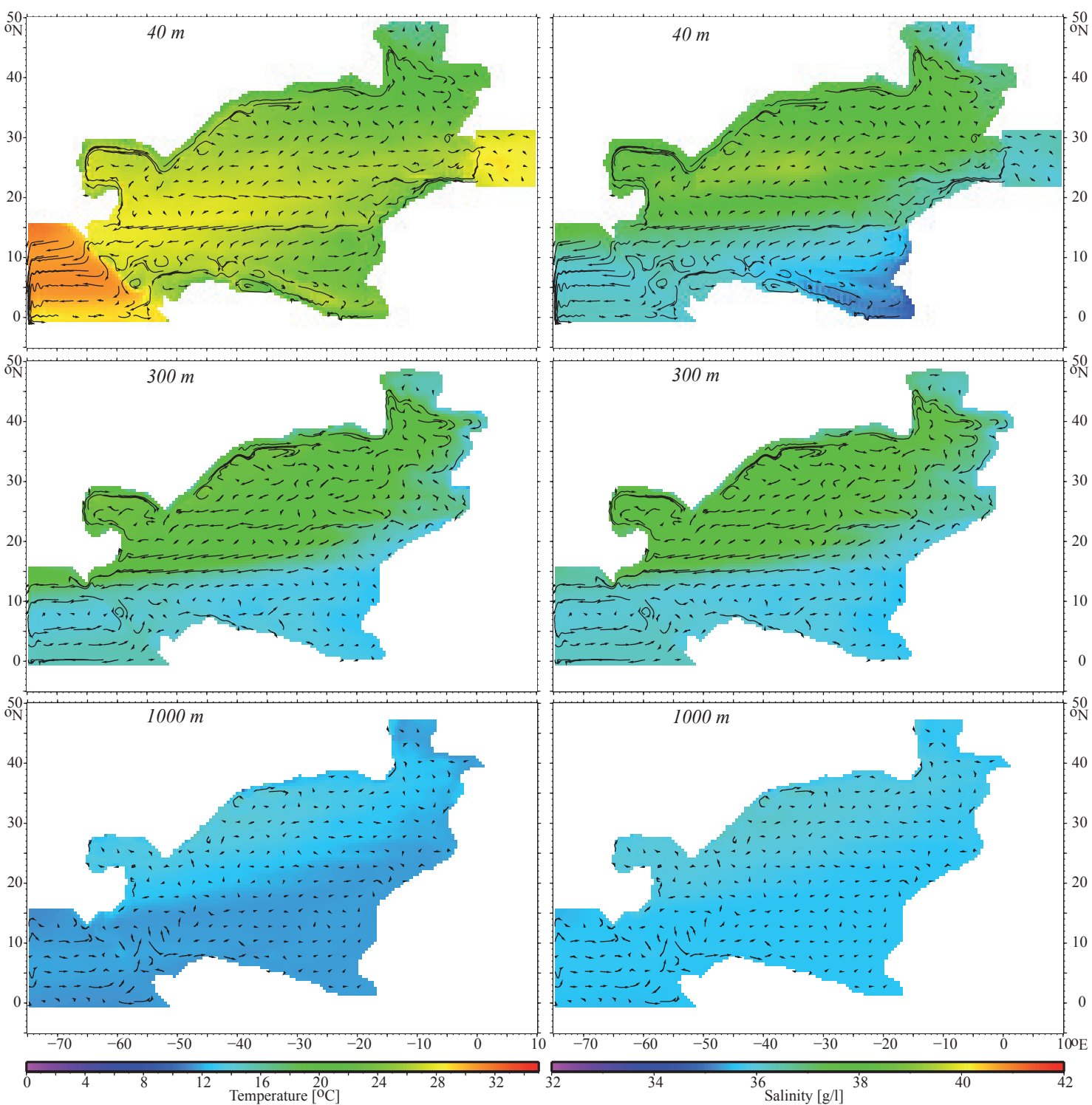

Fig. 11. LOWSL-TET tracer patterns. Temperature (left) and salinity (right) slices taken at depths of 40, 300 and $1000 \mathrm{~m}$ from the LOWSLTET experiment. The paths of waterparticles of every fifth grid point followed for 42,84 and 114 days are overprinted on the tracer colours.

models. However, there is a risk attached to the level of detail at high resolutions. In Sect. 2.2, it became clear that the available palaeogeographical reconstructions differ on important points of the bathymetry, like the CAS depth and width, the presence of an EAS and the possibility of Caribbean Plateau basalts near/in the CAS. The choices that have been made add a certain amount of uncertainty to the model results. The gateway geometry sensitivity tests show that the differences in the tracer (salinity and temperature) and velocity fields when one of the disputed features is changed are small and to some extent predictable.

One of the greatest limitations of the MOMA model is its inability to change the total volume of water within the model. Fresh water fluxes do not add water to the model, but are simulated with a VSF, and more importantly, sponges will always balance their outflow with an inflow from the attached basin. The largest disadvantage of the sponges is their inability to verify whether outflow from the sponge forces inflow from the basin or the other way around. In a global model, inflow does not have to balance outflow because the oceans simulated with the sponges in the regional model are connected to each other outside our regional model domain. There is no easy way to solve this problem. Mainly for the Tethys, the exchange with the sponges includes fluxes which are immediately returned to the sponge without affecting the basin. Fortunately, these are generally limited to the first grid cells of the basin at depths with little volume transport to the basin. 


\subsection{OAE scenario}

\subsubsection{OAE}

OAEs are time envelopes characterised by important perturbations in the global carbon cycle, the records of which are found globally in sedimentary rocks as excursions in the carbon isotope record (e.g. Scholle and Arthur, 1980). However, organic-rich sediments associated with OAEs are mostly found in the North Atlantic Basin and surrounding shelf seas (e.g. Friedrich, 2010; Kuroda and Ohkouchi, 2006). For this reason, it is expected that this ocean basin fulfilled certain conditions favourable for the production and subsequent preservation of organic matter.

Trabucho Alexandre et al. (2010) have recently proposed that a combination of hydrothermal nutrient input to Pacific seawater with a stronger thermohaline circulation and inflow of nutrient-rich Pacific sea water to the North Atlantic was behind the deposition of organic-rich sediments during the mid-Cretaceous. Indeed, the mid-Cretaceous was characterised by enhanced seafloor hydrothermal activity (seafloor spreading, large igneous provinces) which is thought to have resulted in an enhanced input of biolimiting nutrient elements to seawater (Kerr, 1998; Larson and Erba, 1999; Sinton and Duncan, 1997), especially in the Pacific Ocean (Utsunomiya et al., 2007).

The highest sea level stand of the Phanerozoic, which was due to a larger area of relatively more buoyant oceanic lithosphere (Cogne et al., 2006), took place around the Cenomanian-Turonian boundary (Miller et al., 2005; Müller et al., 2008). Such a high sea level resulted in wider shelves where conditions for the production and preservation of organic matter were favourable. Concomitantly, flooding of coastal areas may have delivered an additional small amount of nutrient elements to the ocean while at the same time trapping terrigenous clastics further inshore (Erbacher et al., 1996; Piper and Calvert, 2009; Sageman et al., 2003). Furthermore, a higher sea level stand must have led to an increased water depth in gateways connecting the North Atlantic Basin with the global ocean thus improving intermediate water flow to the more restricted North Atlantic.

Our regional model results are in agreement with the results presented by Trabucho Alexandre et al. (2010) and show (Figs. 3-6) an inflow of Pacific water at intermediate depths moving along the southern margin of the North Atlantic while water from the Tethys flows at the surface in the opposite direction, i.e. towards the Pacific.

The present-day Atlantic Ocean is a meridional basin connecting both polar regions. In the mid-Cretaceous, however, the North Atlantic was part of a tropical east-west seaway, the Tethys. Nevertheless, meridional overturning in the basin was still $18 \mathrm{~Sv}$ with the strongest overturning taking place between 10 and $30^{\circ} \mathrm{N}$ (Trabucho Alexandre et al., 2010). As a consequence of basin physiography and palaeogeography, zonal overturning in the North Atlantic was slightly stronger than the average present-day North Atlantic meridional overturning circulation (21 vs. $18.7 \mathrm{~Sv}$; Cunningham et al., 2007). Therefore, even though a sluggish overturning is often proposed to be behind the development of anoxia during OAEs (Bralower and Thierstein, 1984; Ryan and Cita, 1977), modelling studies have shown this not to be the case and geochemical studies have shown stagnation to be antithetic to the development of anoxic/euxinic conditions (Meyer and Kump, 2008; Otto-Bliesner et al., 2002; Trabucho Alexandre et al., 2010). Our model confirms these previous studies by showing a stronger circulation in the North Atlantic than at present.

Pacific nutrient-rich intermediate water was transported towards the euphotic zone by upwelling in mesoscale eddies and within the broad upwelling zone along the southern margins of the North Atlantic Basin. The enhanced nutrient supply to the euphotic zone thus generated must have led to a sharp increase in primary productivity, which in turn promoted anoxic conditions in the sediments. Under such conditions, phosphorus regeneration, for instance, would have provided a positive feedback to the system and fueled further productivity in the euphotic zone (Ingall et al., 1993; van Cappellen and Ingall, 1994).

Northern North Atlantic surface water only gets a small amount of Pacific nutrient-rich water by upwelling, because most of the Pacific water flows east in the southern part of the North Atlantic Basin. This provides an explanation for the lower organic carbon content of sediments in the northern part of the basin with respect to the southern margins (Kuhnt and Wiedmann, 1995; Tissot et al., 1980).

A strong argument for the proposal that Pacific seawater fuelled black shale formation in the mid-Cretaceous North Atlantic is the agreement between known black shale occurrences and modelled upwelling zones (Fig. 12). All localities with the highest TOC values are located in the modelled upwelling zones along the Gondwanan coasts where our model predicts the strongest upwelling of Pacific water.

\subsubsection{Pre-OAE}

Prior to OAE2, sea levels were relatively low (Miller et al., 2005), epicontinental seas were basically absent and pericontinental shelves were relatively narrow (Thiede, 1979). Organic-rich sediments were deposited only locally (e.g. Demerara Rise, Tarfaya) with TOC values far below OAE values $(\leq 10 \%)$ (e.g. Summerhayes, 1981). Our experiments (LOWSL and LOWSL-TET) show that the Tethyan inflow and zonal overturning rates decrease significantly as a consequence of a lower sea level stand, the exact decrease being determined by the depth of the PSoG.

The reduced overturning is partly due to decreased rates and the extent of upwelling zones and partly due to a reduced exchange with the global ocean. While in the OAE experiment (REF) dense water was formed on epicontinental shelves creating overturning along the coast, in the pre-OAE 


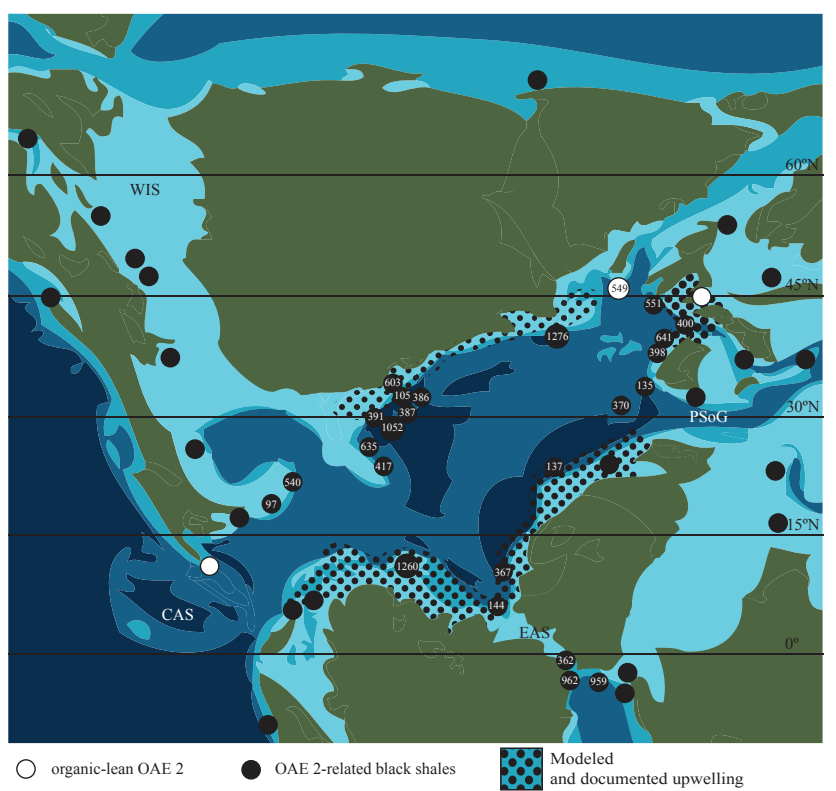

Fig. 12. High total organic carbon map. All localities with the highest total organic carbon (TOC) values are located in the modelled upwelling zones along the Gondwanan coasts where our model predicts the strongest upwelling of Pacific water. Numbers indicate DSDP/ODP sites.

scenario the small shelves limit dense water formation and consequently upwelling is further decreased.

The decreased inflow of Pacific water (ca. $10 \mathrm{~Sv}$ ), of which the majority is intermediate inflow, probably had a negative impact on nutrient supply to upwelling zones in the North Atlantic. The combination of decreased overturning and upwelling in the pre-OAE scenario thus led to less favourable conditions for the production and preservation of organic matter in marine sediments.

\subsubsection{Post-OAE}

The SATL experiment shows that the opening of the EAS, the timing of which is still a matter of discussion (Moulin et al., 2009, and references therein), leads to significant changes in the model patterns previously described here. The upwelling of water with a Pacific origin in the southern part of the North Atlantic Basin is disturbed and limited to a small area away from the South Atlantic inflow.

The increased upwelling along the North American coast caused by the northward push and deflection of deep water and Pacific inflow, respectively, which takes place when the EAS is open, should have caused an increase in organic matter deposition on the eastern North American shelf seafloor. Since this is not supported by geologic data for the OAE2 interval (Summerhayes, 1981; Tissot et al., 1980), a model with an open EAS does not seem to represent conditions during this interval.
The areas where upwelling persists in the model after the opening of the EAS correspond well to localities where black shale deposition continued across the Cenomanian-Turonian boundary. The La Luna Formation in Venezuela (Romero et al., 2003) and the lateral equivalent of the Plantagenet Formation at Demerara Rise (ODP Leg 207, Berrocoso et al., 2008; Hardas and Mutterlose, 2006) are therefore likely to be the products of organic productivity driven by upwelling of nutrient-rich Pacific water well after OAE2 and the opening of the EAS.

In our model, the opening of the EAS does not result in a freshening of the North Atlantic as found in the global model study of Poulsen et al. (2001). Instead, basin-averaged salinity and temperature increase with respect to REF. The differences in the results between the global and regional model results are probably caused by significant differences in the gateway bathymetries used as well as the South Atlantic tracer composition.

In the open EAS scenario, the overturning in the North Atlantic is vigorous in both zonal and meridional components and extends downwards well below $4000 \mathrm{~m}$ depth. Water column anoxic conditions, let alone euxinic, are extremely difficult to generate under such conditions, as deep water is constantly supplied with new oxygen from the surface layers. Decreased primary productivity in combination with vigorous ocean circulation and upwelling of South Atlantic seawater instead of Pacific seawater along the margins of the basin must have led to a decreased oxygen demand and to less organic matter deposition and preservation in these areas.

\section{Conclusions}

A regional ocean circulation model for the North Atlantic basin during the Cenomanian-Turonian OAE2 has been developed and can be compared with a global ocean circulation model for the same time interval, a Cenomanian CCSM3 run. Boundary and initial conditions used were also obtained from this global model. Tracer distribution, horizontal velocities and upwelling patterns in the two models are similar for a regional model configuration with connections to the global ocean through the CAS and PSoG. This similarity of results proves that a regional model can be used as a high resolution tool next to global models for studying OAE2. The high resolution can be exploited when the upwelling patterns found are compared with known black shale occurrences. The match between upwelling and the black shale deposits found is a large step forward in the prediction of undiscovered deposits.

Different gateway geometries in the CAS and PSoG have little effect on tracer distribution in the North Atlantic, but do affect overturning and upwelling.

Lowering sea level in a pre-OAE scenario decreases the areal extent of upwelling zones, the rate of upwelling, the 
strength of overturning and supply of Pacific water. Together, these suggest a lower organic matter production and the absence of organic-rich black shale deposition along most of the southern coasts.

The enhanced primary production during OAE2 could have been caused by an increased amount of available nutrients of Pacific origin in the upwelling zones in the south part of the basin as confirmed by the regional model results.

The opening of the EAS interrupts the supply of nutrientrich Pacific water to the South American and African coastal zones, decreasing the primary productivity. Furthermore, vigorous overturning supplies the deep basin with oxygen to prevent sustained anoxic conditions.

\section{Supplementary material related to this article is available online at: http://www.clim-past.net/7/277/2011/ cp-7-277-2011-supplement.pdf.}

Acknowledgements. We thank Michael Kliphuis for providing us with the CCSM3 data and technical support, and W. W. Hay and an anonymous referee for constructive comments. RPMT is supported by the Netherlands Research Centre for Integrated Solid Earth Science (ISES). Computational resources for this work were provided by the Netherlands Research Centre for Integrated Solid Earth Science (ISES 3.2.5 High End Scientific Computation Resources). The figures have been prepared using GMT (Wessel and Smith, 1998).

Edited by: V. Brovkin

\section{References}

Barron, E. J. and Peterson, W. H.: The Cenozoic ocean circulation based on ocean General Circulation Model results, Palaeogeogr. Palaeocl., 83, 1-28, 1991.

Barron, E. J. and Washington, W. M.: The carbon cycle and atmospheric $\mathrm{CO}_{2}$ : Natural variations from Archean to present; Proceedings of the Chapman Conference on Natural Variations in Carbon Dioxide and the Carbon Cycle, Tarpon Springs, FL, 913 January 1984, (A86-39426 18-46), chap. Warm Cretaceous climates - High atmospheric $\mathrm{CO}_{2}$ as a plausible mechanism, 1985.

Berrocoso, A. J., MacLeod, K. G., Calvert, S. E., and Elorza, J.: Bottom water anoxia, inoceramid colonization, and benthopelagic coupling during black shale deposition on Demerara Rise (Late Cretaceous western tropical North Atlantic), Paleoceanography, 23(3), PA3212, doi:10.1029/2007PA001545, 2008.

Bralower, T. J. and Thierstein, H. R.: Low productivity and slow deep-water circulation in mid-Cretaceous oceans, Geology, 12, 614-618, 1984.

Bryan, K.: A numerical method for the study of the circulation of the world ocean, J. Comput. Phys., 4, 347-376, 1969.

Bryan, K. and Cox, M. D.: A numerical investigation of the ocean circulation, Tellus, 1967.
Cogne, J. P., Humler, E., and Courtillot, V.: Mean age of oceanic lithosphere drives eustatic sea-level change since Pangea breakup, Earth Planet. Sc. Lett., 245, 115-122, 2006.

Collins, W. D., Bitz, C. M., Blackmon, M. L., Bonan, G. B., Bretherton, C. S., Carton, J. A., Chang, P., Doney, S. C., Hack, J. J., Henderson, T. B., Kiehl, J. T., Large, W. G., McKenna, D. S., Santer, B. D., and Smith, R. D.: The Community Climate System Model Version 3 (CCSM3), J. Climate, 19, 2122-2143, 2006.

Cox, M. D.: A mathemathical model of the Indian Ocean, Deep-sea Research and Oceanographic Abstracts, 1970.

Cunningham, S. A., Kanzow, T., Rayner, D., Baringer, M. O., Johns, W. E., Marotzke, J., Longworth, H. R., Grant, E. M., Hirschi, J. J. M., Beal, L. M., Meinen, C. S., and Bryden, H. L.: Temporal variability of the Atlantic meridional overturning circulation at $26.5^{\circ} \mathrm{N}$, Science, 317, 935-938, doi:10.1126/science.1141304, 2007.

Erbacher, J., Thurow, J., and Littke, R.: Evolution patterns of radiolaria and organic matter variations: a new approach to identify sea-level changes in mid-Cretaceous pelagic environments, Geology, 24, 499-502, 1996.

Fofonoff, N. P. and Millard, R. C.: Algorithms for computation of fundamental properties of seawater, Unesco Technical Papers in Marine Science, 44, 1983.

Friedrich, O.: Benthic foraminifera and their role to decipher paleoenvironment during mid-Cretaceous Oceanic Anoxic Events - the "anoxic benthic foraminifera" paradox, Revue de micropaléontologie, 53(3), 175-192, doi:10.1016/j.revmic.2009.06.001, 2010.

Friedrich, O. and Erbacher, J.: Benthic foraminiferal assemblages from Demarara Rise (ODP Leg 207, western tropical Atlantic): possible evidence for a progressive opening of the Equatorial Atlantic Gateway, Cretaceous Res., 27, 377-397, 2006.

Haines, K. and Wu, P.: GCM studies of intermediate and deepwaters in the Mediterranean, J. Mar. Syst., 18, 197-214, 1998.

Handoh, I. C., Bigg, G. R., Jones, E. J. W., and Inoue, M.: An ocean modeling study of the Cenomanian Atlantic: equatorial paleo-upwelling, organic-rich sediments and the consequences for a connection between the proto-North and South Atlantic, Geophys. Res. Lett., 26, 223-226, 1999.

Haq, B. U., Hardenbol, J., and Vail, P. R.: Chronology of fluctuating sea levels since the Triassic, Science, 235, 1156-1167, 1987.

Hardas, P. and Mutterlose, J.: Calcareous nannofossil biostratigraphy of the Cenomanian/Turonian boundary interval of ODP Leg 207 at the Demerara Rise, Revue de micropaléontologie, 49, 165-179, 2006.

Ingall, E. D., Bustin, R. M., and van Cappellen, P.: Influence of water column anoxia on the burial and preservation of carbon and phosphorus in marine shales, Geochim. Cosmochim. Acta, 57, 303-316, 1993.

Jeans, C. V., Long, D., Hall, M. A., Bland, D. J., and Cornford, C.: The geochemistry of the Plenus Marls at Dover, England: evidence of fluctuating oceanographic conditions and of glacial control during the development of the Cenomanian-Turonian $\delta^{13} \mathrm{C}$ anomaly, Geol. Mag., 128, 603-632, 1991.

Jenkyns, H. C.: Cretaceous anoxic events: From continents to oceans, J. Geol. Soc. Lond., 137, 171-188, 1980. 
Jones, E. J. W., Cande, S. C., and Spathopoulos, F.: Evolution of a major oceanographic pathway: the equatorial atlantic, Special Publications, Geol. Soc. Lond., 90, 199-213, 1995.

Kerr, A. C.: Oceanic plateau formation: a cause of mass extinction and black shale deposition around the Cenomanian-Turonian boundary?, J. Geol. Soc. Lond., 155, 619-626, 1998.

Kolonic, S., Wagner, T., Forster, A., Sinninghe Damsté, J. S., Walsworth-Bell, B., Erba, E., Turgeon, S., Brumsack, H. J., Chellai, E. H., Tsikos, H., Kuhnt, W., and Kuypers, M. M. M.: Black shale deposition on the northwest African Shelf during the Cenomanian/Turonian oceanic anoxic event: Climate coupling and global organic carbon burial, Paleoceanography, 20, PA1006, doi:10.1029/2003PA000950, 2005.

Kuhnt, W. and Wiedmann, J.: Cenomanian-Turonian source rocks: paleobiogeographic and paleoenvironmental aspects, in: Paleogeography, Tulsa, Oklahoma, 213-231, 1995.

Kuroda, J. and Ohkouchi, N.: Implication of spatiotemporal distribution of black shales deposited during the Cretaceous Oceanic Anoxic Event-2, Paleontol. Res., 10, 345-358, 2006.

Kuypers, M. M. M., Pancost, R. D., Nijenhuis, I. A., and Sinninghe Damsté, J. S.: Enhanced productivity led to increased orgainc carbon burial in the euxinic North Atlantic basin during the late Cenomanian oceanic anoxic event, Paleoceanography, 17, 10511063, 2002.

Kuypers, M. M. M., Lourens, L. J., Rijpstra, W. I. C., Pancost, R. D., Nijenhuis, I. A., and Sinninghe Damsté, J. S.: Orbital forcing of organic carbon burial in the proto-North Atlantic during oceanic anoxic event 2, Earth Planet. Sc. Lett., 228, 465-482, 2004a.

Kuypers, M. M. M., van Breugel, Y., Schouten, S., Erba, E., and Sinninghe Damsté, J. S.: $\mathrm{N}_{2}$-fixing cyanobacteria supplied nutrient $\mathrm{N}$ for Cretaceous oceanic anoxic events, Geology, 32, 853856, 2004b.

Larson, R. L. and Erba, E.: Onset of the mid-Cretaceous greenhouse in the Barremian-Aptian: Igneous events and the biological, sedimentary, and geochemical responses, Paleoceanography, 14, 663-678, 1999.

Meijer, P. T., Slingerland, R., and Wortel, M. J. R.: Tectonic control on past circulation of the Medittanean Sea: a model study of the Late Miocene, Paleoceanography, 19, PA1026, doi:10.1029/2003PA000956, 2004.

Meschede, M. and Frisch, W.: A plate-tectonic model for the Mesozoic and Early Cenozoic history of the Caribbean plate, Tectonophysics, 296, 269-291, 1998.

Meyer, K. M. and Kump, L. R.: Oceanic euxinia in Earth history: causes and consequences, Annu. Rev. Earth Pl. Sc., 36, 251-288, 2008.

Miller, K. G., Kominz, M. A., Browning, J. V., Wright, J. D., Mountain, G. S., Katz, M. E., Sugerman, P. J., Cramer, B. S., Cristie-Blick, N., and Pekar, S. F.: The Phanerozoic record of global sea-level change, Science, 310, 1293-1298, doi:10.1126/science.1116412, 2005.

Mort, H., Jacquat, O., Adatte, T., Steinmann, P., Föllmi, K., Matera, V., Berner, Z., and Stüben, D.: The Cenomanian-Turonian anoxic event at the Bonarelli Level in Italy and Spain: enhanced productivity and/or better preservation?, Cretaceous Res., 28, 597-612, 2007.
Moulin, M., Aslanian, D., and Unternehr, P.: A new starting point for the South and Equatorial Atlantic Ocean, Earth-Sci. Rev., 97, 59-95, 2009.

Müller, R. D., Sdrolias, M., Gaina, C., Steinberger, B., and Heine, C.: Long-term sea-level fluctuations driven by ocean basin dynamics, Science, 319, 1357-1362, 2008.

Otto-Bliesner, B. L., Brady, E. C., and Shields, C.: Late Cretaceous ocean: coupled simulations with the national center for atmospheric research climate system model, J. Geophys. Res.-Atmos., 107, 4019, doi:10.1029/2001JD000821, 2002.

Pacanowski, R. C.: MOM2 documentation: Users guide and reference manual, Version 1.0., GFDL Ocean Group Technical Report No. 3, Tech. rep., Geophysical Fluid Dynamics Laboratory, Princeton, New Jersey, 1995.

Pacanowski, R. C. and Griffies, S. M.: The MOM3 Manual, GFDL Ocean Group Technical Report No. 4, Tech. rep., NOAA/Geophysical Fluid Dynamics Laboratory, Princeton, New Jersey, 1999.

Parrish, J. T. and Curtis, R. L.: Atmospheric circulation, upwelling and organic-rich rocks in the Mesozoic and Cenozoic eras, Palaeogeogr. Palaeocl., 40, 31-66, 1982.

Philander, S. G. H., Jurlin, W. J., and Siegel, A. D.: Simulation of the seasonal cycle of tropical Pacific Ocean, J. Phys. Oceanogr., 17, 1986-2002, 1987.

Pindell, J. and Dewey, J. F.: Permo-Triassic reconstruction of western Pangea and the evolution of the Gulf of Mexico, Tectonics, 1, 179-211, 1982.

Piper, D. Z. and Calvert, S. E.: A marine biogeochemical perspective on black shale deposition, Earth-Sci. Rev., 95, 63-96, 2009.

Pletsch, T., Erbacher, J., Holbourn, A. E. L., Kuhnt, W., Moullade, M., Oboh-Ikuenobede, F. E., Söding, E., and Wagner, T.: Cretaceous separation of Africa and South America: the view from the West African margin (ODP Leg 159), J. S. Am. Earth Sci., 14, 147-174, 2001.

Poulsen, C. J., Barron, E. J., Arthur, M. A., and Peterson, W. H.: Response of the mid-Cretaceous global oceanic circulation to tectonic and $\mathrm{CO}_{2}$ forcings, Paleoceanography, 16, 576-592, 2001.

Poulsen, C. J., Gendaszek, A. S., and Jacob, R. L.: Did the rifting of the Atlantic Ocean cause the Cretaceous thermal maximum?, Geology, 31, 115-118, 2003.

Rahmstorf, S.: Multiple convection patterns and thermohaline flow in an idealized OGCM, J. Climate, 8, 3028-3039, 1995.

Rahmstorf, S. and Willebrand, J.: The role of temperature feedback in stabilizing the thermohaline circulation, J. Phys. Oceanogr., 25, 787-805, 1995.

Romero, L. M. D., Truskowski, I. M., Bralower, T. J., Bergen, J. A., Odreman, O., Zachos, J. C., and Galea-Alvares, F. A.: An integrated calcareous microfossil biostratigraphic and carbonisotope stratigraphic framework for the La Luna Formation, western Venezuela, Palaios, 18, 349-366, 2003.

Ross, M. I. and Scotese, C. R.: A hierarchical tectonic model of the Gulf of Mexico and Caribbean region, Tectonophysics, 155, 139-168, 1988.

Roussenov, V. M., Stanev, E., Artale, V., and Pinardi, N.: A seasonal model of the Mediterranean Sea general circulation, J. Geophys. Res., 100, 13515-13538, 1995.

Ryan, W. B. F. and Cita, M. B.: Ignorance concerning episodes of ocean-wide stagnation, Mar. Geol., 23, 197-215, 1977. 
Sageman, B. B., Murphy, A. E., Wern, J. P., Verstraeten, C. A., Hollander, D. J., and Lyons, T. W.: A tale of shales: the relative roles of production, decomposition, and dilution in the accumulation of organic-rich strata, Middle-Upper Devonian, Appalachian basin, Chem. Geol., 195, 229-273, 2003.

Sageman, B. B., Meyers, S. R., and Arthur, M. A.: Orbital time scale and new C-isotope record for Cenomanian-Turonian boundary stratotype, Geology, 34, 125-128, 2006.

Schlanger, S. O. and Jenkyns, H. C.: Cretaceous Oceanic Anoxic Events: Causes and consequences, Geologie en Mijnbouw, 55, 179-184, 1976.

Scholle, P. A. and Arthur, M. A.: Carbon isotope fluctuations in Cretaceous pelagic limestones: potential stratigraphic and petroleum exploration tool, AAPG Bull., 64, 67-87, 1980.

Sewall, J. O., van de Wal, R. S. W., van der Zwan, K., van Oosterhout, C., Dijkstra, H. A., and Scotese, C. R.: Climate model boundary conditions for four Cretaceous time slices, Clim. Past, 3, 647-657, doi:10.5194/cp-3-647-2007, 2007.

Sinninghe Damsté, J. S. and Köster, J.: A euxinic southern North Atlantic Ocean during the Cenomanian/Turonian oceanic anoxic event, Earth Planet. Sc. Lett., 158, 165-173, 1998.

Sinton, C. W. and Duncan, R. A.: Potential links between ocean plateau volcanism and global ocean anoxia at the CenomanianTuronian boundary, Econ. Geol., 92, 836-842, 1997.

Summerhayes, C. P.: Organic facies of Middle Cretaceous black shales in deep North Atlantic, AAPG Bull., 65, 2364-2380, 1981.

Thiede, J.: Paleogeography and paleobathymetry of the Mesozoic and Cenozoic North Atlantic Ocean, Geojournal, 3, 263-272, 1979.

Tissot, B., Demaison, G. J., Masson, P., Delteil, J. R., and Combaz, A.: Paleoenvironment and Petroleum Potential of Middle Cretaceous Black Shales in Atlantic Basins, AAPG Bull., 64, 2051-2063, 1980.
Trabucho Alexandre, J., Tuenter, E., Henstra, G. A., van der Zwan, C. J., van de Wal, R. S. W., Dijkstra, H. A., and de Boer, P. L.: The mid-Cretaceous North Atlantic nutrient trap: black shales and OAEs, Paleoceanography, 25(4), PA4201, doi:10.1029/2010PA001925, 2010.

Utsunomiya, A., Ota, T., Windley, B. F., Suzuki, N., Uchio, Y., Munekata, K., and Maruyama, S.: Superplumes: beyond plate tectonics, chap. History of the Pacific superplume: implications for Pacific paleogeography since the Late Proterozoic, Springer, New York, 363-408, 2007.

van Bentum, E. C., Hetzel, A., Brumsack, H. J., Forster, A., Reichart, G. J., and Sinninghe Damsté, J. S.: Reconstruction of water column anoxia in the equatorial Atlantic during the Cenomanian-Turonian oceanic anoxic event using biomarker and trace metal proxies, Palaeogeogr. Palaeocl., 280, 489-498, 2009.

van Cappellen, P. and Ingall, E. D.: Benthic phosphorus regeneration, net primary production, and ocean anoxia: a model of the coupled marine biogeochemical cycles of carbon and phosphorus, Paleoceanography, 9, 677-692, 1994.

Webb, D. J., Coward, A. C., de Cuevas, B. A., and Gwilliam, C. S.: A multiprocessor ocean general circulation model using message passing, J. Atmos. Ocean. Tech., 14, 175-183, 1997.

Wessel, P. and Smith, W. H. F.: New, improved version of the Generic Mapping Tools released, EOS, Transactions, American Geophysical Union, 79, 579 pp., 1998.

Yin, J., Stouffer, R. J., Spelman, M. J., and Griffies, S. M.: Evaluating the Uncertainty Induced by the Virtual Salt Flux Assumption in Climate Simulations and Future Projections, J. Climate, 23, 80-96, 2010. 